\title{
E-Waste and Its Consequence for Environment and Public Health: Perspectives in Covid-19 Pandemic Times
}

\author{
Joselito Nardy Ribeiro ${ }^{1}$, Angelo Fernando Melo Barbosa ${ }^{2}$, Araceli Veronica Flores Nardy Ribeiro ${ }^{2}$, \\ Madson de Godoi Pereira ${ }^{3}$, Jairo Pinto de Oliveira ${ }^{1}$, Alan Bragança Zordan ${ }^{1} \&$ André Romero da Silva ${ }^{4}$ \\ ${ }^{1}$ Science Health Center, Federal University of Espirito Santo-UFES, Vitoria-ES, Brazil \\ ${ }^{2}$ Federal Institute of Espírito Santo-IFES, Vila Velha-ES, Brazil \\ ${ }^{3}$ Department of Earth Science, University of Bahia State, Salvador-BA, Brazil \\ ${ }^{4}$ Federal Institute of Espirito Santo-IFES, Aracruz-ES, Brazil \\ Correspondence: Joselito Nardy Ribeiro, Science Health Center, Federal University of Espirito Santo-UFES, \\ Vitoria-ES, Brazil. E-mail: rinajokrauser@gmail.com
}

Received: December 26, 2021 Accepted: February 9, 2022 Online Published: February 17, 2022

doi:10.5539/gjhs.v14n3p54

URL: https://doi.org/10.5539/gjhs.v14n3p54

\begin{abstract}
Every year the electronics industry increases its production and earns billions of dollars. This increase is associated to the growth electronic waste production that, unfortunately, is not followed by the proportional recycling increase. An extensive quantity of e-waste containing several toxic chemical residues, that provoke serious toxic effects for human health, is released in the environment every day. This work it is a mini review about the issue of electronic waste production and its chemical contamination capacity for soil, water, plants, animals, food, and humans. Finally, this mini-review finalize with a small reflection about e-waste in Covid-19's Pandemic times.
\end{abstract}

Keywords: e-waste, environment, public health, Covid-19

\section{Introduction}

Despite various governments, industrial sectors, and environmental organizations to report a considerable evolution in the reuse and recycle of electronic waste, the reality is not so exciting. A lot of documentaries from tv and videos channels, besides news sites, books, and scientific articles have been show the negative effects of nonconventional and rudimentary methods to recycle metals from e-waste. These informal activities are considered dangerous because to generate large amounts of residues containing extremely toxic metals and organic chemical pollutants that cause serious health problems and dramatically decrease the life expectancy of the population, mainly around contaminated areas near e-waste (Sthiannopkao, 2013; Bradley, 2014; Lecher, 2019; Bazilian, 2020; Hameed, 2020). This informal subsistence economy is the only source income a lot of populations located in some areas of many countries such as: Ghana (Buzuev, 2015), Nigeria (Nnorom and Osibanjo, 2008), India (Borthakur and Singh, 2012), Pakistan (Iqbal et al., 2017), Philippines, Indonesia, Vietnam (Youshida et al., 2016), Mexico (Cruz-Sotelo et al., 2017), Malaysia (Suja et al., 2014), Hong Kong (Bhattacharya, 2017), and several other parts of the world, mainly in poor and developing countries (Maphosa et al., 2017). In Ethiopia, for example, the high rate of brokens cell phones, the accelerated increasing of obsolescence rate, and the demand for new technology are the main causes for the e-waste generation. Commonly storing is the major practiced disposal method as well as recycling and donating. However, Kitila and Woldemikael (2021) demonstrate that absence of efficient recycle and appropriate disposal methods are the main factors for the storage, improper disposal and rudimentary. In other article published in 2019, the same authors reported several problems to treat the electronic waste from educational institutions and government sector offices of Addis Ababa (Kitila and Woldemikael, 2019).

Recent data collected from The Global E-Waste Statistics Partnership Website demonstrate that Ghana situation is not different (Global E-Waste: Ghana, 2019). Interestingly this important website does not reveal the amount of e-waste imported from US, and Europe by Ghana. Perhaps due to the lack of data provided by the local government. However, it should not be difficult to measure the many tons of e-waste discarded in this African country by developed countries. In the e-waste import zone situated in Agbogbloshie, a region localized in the heart of Accra Province, the view it reveals a catastrophic scenario showing various unconventional treatment 
points of toxic e-waste containing fume and water probably contaminated by chemical pollutants, beside urban conflicts between pickers, and other social problems (Minter, 2016; Daum et al., 2017; Petricca et al., 2020). The e-waste problem is also a reality in South America. For example, in Paraguay does not exist official data about e-waste produced by Paraguayan population. Data collected from the Global E-Waste Statistics Partnership (Global E-Waste: Paraguay, 2019) provides an idea about the e-waste formally collected. However, it does not reveal the amount of e-waste collected by pickers that living directly of this informal job. So, you ask yourself: what is the fate of this material? It is likely to be delivered to recyclers using unconventional and dangerous methods for metals recuperation. Paraguay does not have a specific law for e-waste. However, in its constitution, there are several items that protect the right to a protected environment and good life quality (ABC, 2006). But in relation to e-waste, data presented in 2014 reveal that in Paraguay, each person produces $4.9 \mathrm{~kg}$ of this kind of waste, while in its neighboring country ,Brazil, much more populous, each person produces $7.7 \mathrm{~kg}$. Therefore, the problem of electronic waste in Paraguay cannot be disregarded (Baldé et al., 2014).

In Brazil, Country frontier with Paraguay, recent data collected from The Global E-Waste Statistics Partnership demonstrate that the situation in this Country is worrying. Brazil generated, in 2019, approximately $2143 \mathrm{kt}$ of electronic waste and its formal recycling rate was 0\% (Global E-Waste: Brazil, 2019). Considering that in Brazil the consumption of electronic devices, mainly cell phones (Lopes, 2018), is extremely high, the data presented by the Global E-Waste Statistics Partnership are worrying. The rates of formal e-waste collect obtained from the Global E-Waste Statistics Partnership Website (Global E-Waste: Brazil, 2019) allowed the elaboration of the graph presented in Figure 1. Its possible verified that in Latin America, Brazil does not have formal e-waste collect ( $0 \%)$ while Argentina and Chile formally collect around 3\%, and Peru and Colombia collect around 1\%. However, in some informal meetings with pickers that living in the streets of Vitória-ES $\left(20^{\circ} 19^{\prime} 09^{\prime}\right.$ south latitude and $40^{\circ} 20^{\prime} 50^{\prime}$ west longitude), Espírito Santo State Capital, we have been informed that a large part of this electronic waste is exploited by conventional and unconventional methods (Figure 2) as a secondary source of valuable metals. Some small companies buy this e-waste for possible recycle or to sell to large companies. However, there are no official data to support this information. The reasons for the lack of this official data are also unknown. We can suggest that for these companies, the unconventional e-waste collect has a lower cost because the e-waste is obtained from pickers that accept low payments to their survive.

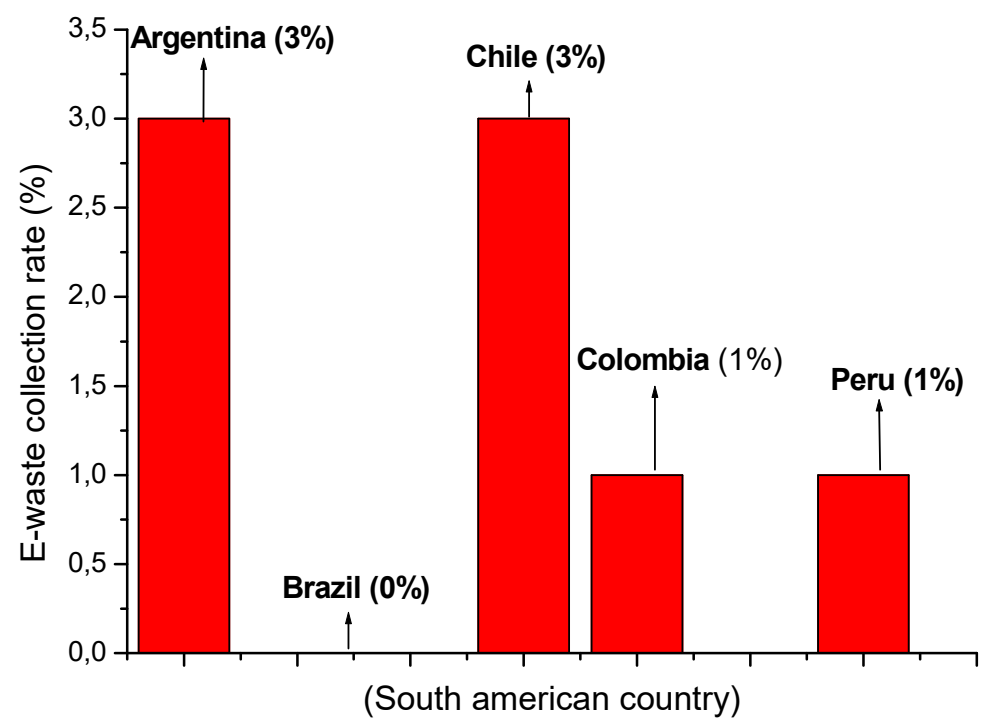

Figure 1. South American countries with formal e-waste collect in comparison with Brazil. (These data were obtained from The Global E-Waste Statistics Partnership, 2019) 


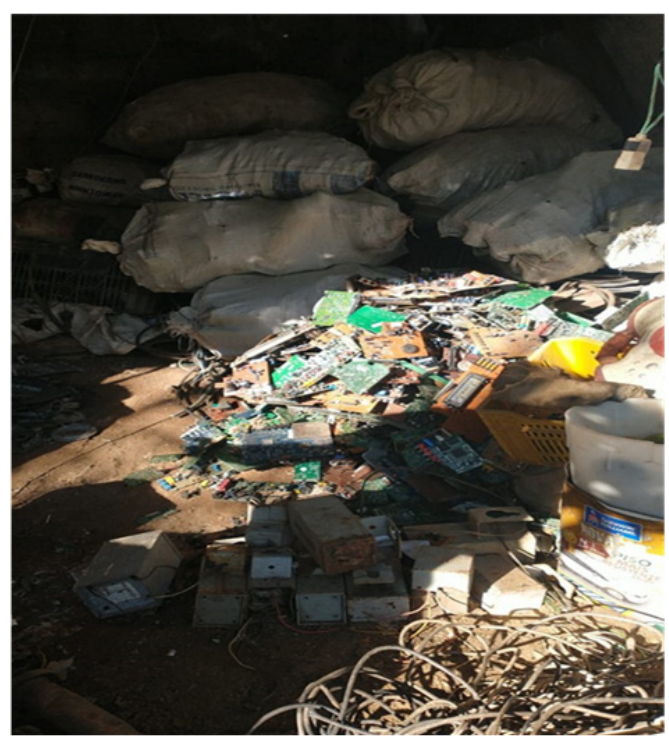

Figure 2. Small deposit of e-waste informally collected in Vitoria-ES, Brazil (Photo: Gustavo Malini Barcelos)

In this mini review the problems caused by chemical pollutants due excessive number of electronic devices discharged in environmental in the last times. It is currently verified that the significant amount e-waste occurs because some important factors such as: the planned obsolescence induced by electronic device industries and the incessant search by news technologies that involve avid consumers hypnotized by globalist media. This behavior provokes serious environmental impacts. Do you think that your old cell phone disappears after use time to another spatial dimension? Your discarded cell phone is part of e-waste destined to poor and developing countries. In these places, the e-waste deposits are used for unconventional and rude recycle, to obtain metals of considerable economic value. These methods are responsible by several environmental problems.

\section{Objectives}

This mini review aims to help clarify the impacts caused by the high e-waste disposal in the environment as well as the harm caused by it in environment and health. In addition, it warns to the increase in disposal caused by the growth consumption during COVID-19 pandemic. Finally, it suggests environmental education as a means of preventing worse damage.

\section{Material and Methods}

Were used the following data banks to obtain the sources present in this mini review: Portal Capes of Brazilian Government, WebofScience, PubMed, Google Scholar and Brazil's Scielo as well as sources from geography sites, online newspapers, online magazines, and blogs.

In this mini review were use "e-waste" word combinate with following keywords: cell phone", contamination, metals, chemical organic pollutants, disease, water, fume, air, soil, animal, plants, humans, milk, blood, Covid-19, and other.

\section{Results and Discussion}

\subsection{E-Waste Contamination}

The Figure 3 represents the consumption dream of many people. But for most of them, the final disposal of these products does not matter. 


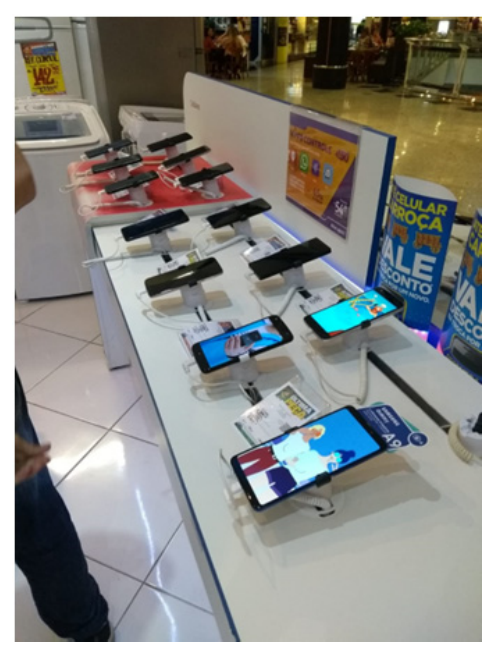

Figure 3. Cell phone store in a typical mall's Brazilian city (Photo: Angelo Fernando Melo Barbosa)

Do you have knowledge about as your cell phone is discarded in environmental? Do you have knowledge about the chemical composition of your cell phone (Singh et al., 2018) (Figure 4) and its consequence to the environment and public health?

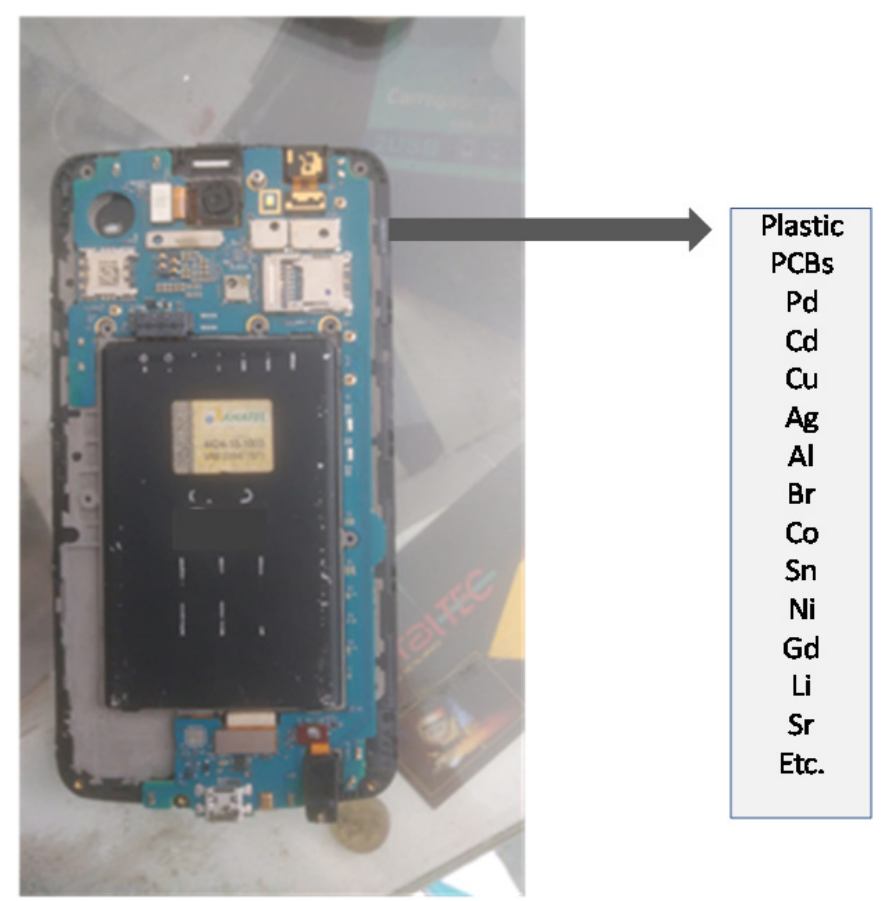

Figure 4. Plastic, polychlorinated biphenyls (PCBs), and metals present in cell phone (Photo: Angelo Fernando Melo Barbosa)

The e-waste presents several metals of economic, strategic, technological interest such as: $\mathrm{Fe}, \mathrm{Cu}, \mathrm{Al}, \mathrm{Co}, \mathrm{Ni}, \mathrm{Sn}$, $\mathrm{Pb}, \mathrm{Cd}, \mathrm{Zn}$, and valuable metals $(\mathrm{Au}, \mathrm{Ag}, \mathrm{Pt}$ and $\mathrm{Pd})$, which represent great interest for their economic value (Alsheyab, 2015). However, there are estimated 1000 toxic substances from e-waste that can threaten the living beings and the environment if not properly treated. Toxic metals and organic compounds such as polycyclic aromatic hydrocarbons (PAHs) and polychlorinated biphenyls (PCBs) are the main concerns (Abdelbasir et al., 2018). Utilizing the keywords: "e-waste and pollution" in the Brazilian Government Data Bank's scientific articles (Capes, 2000), between year's 2010 to 2020, was possible to determine the evolution number of scientific articles published in the world about environmental contamination by e-waste (Figure 5) and recycling (Figure 6). 


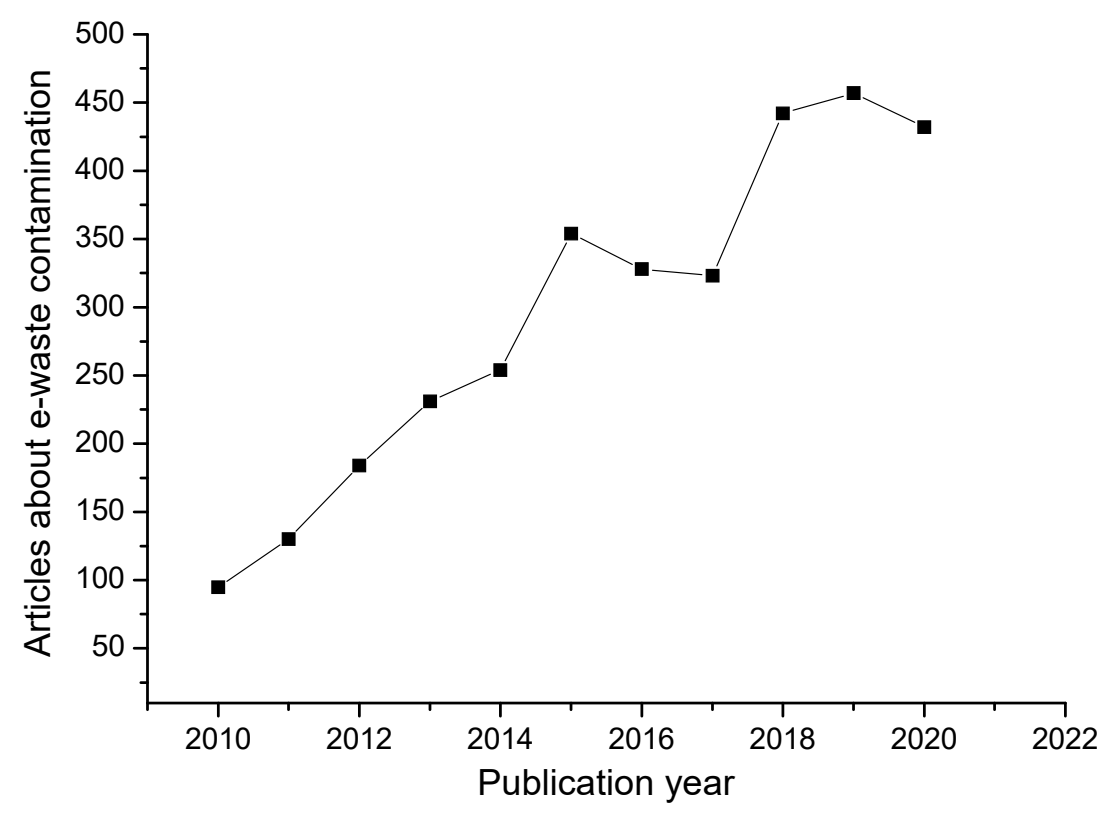

Figure 5. Number of articles about e-waste environmental contamination between year's 2010 and 2020 . These data were obtained from Brazilian Government Data Bank for scientific publications, between year's 2010 to 2020

(Capes, 2000)

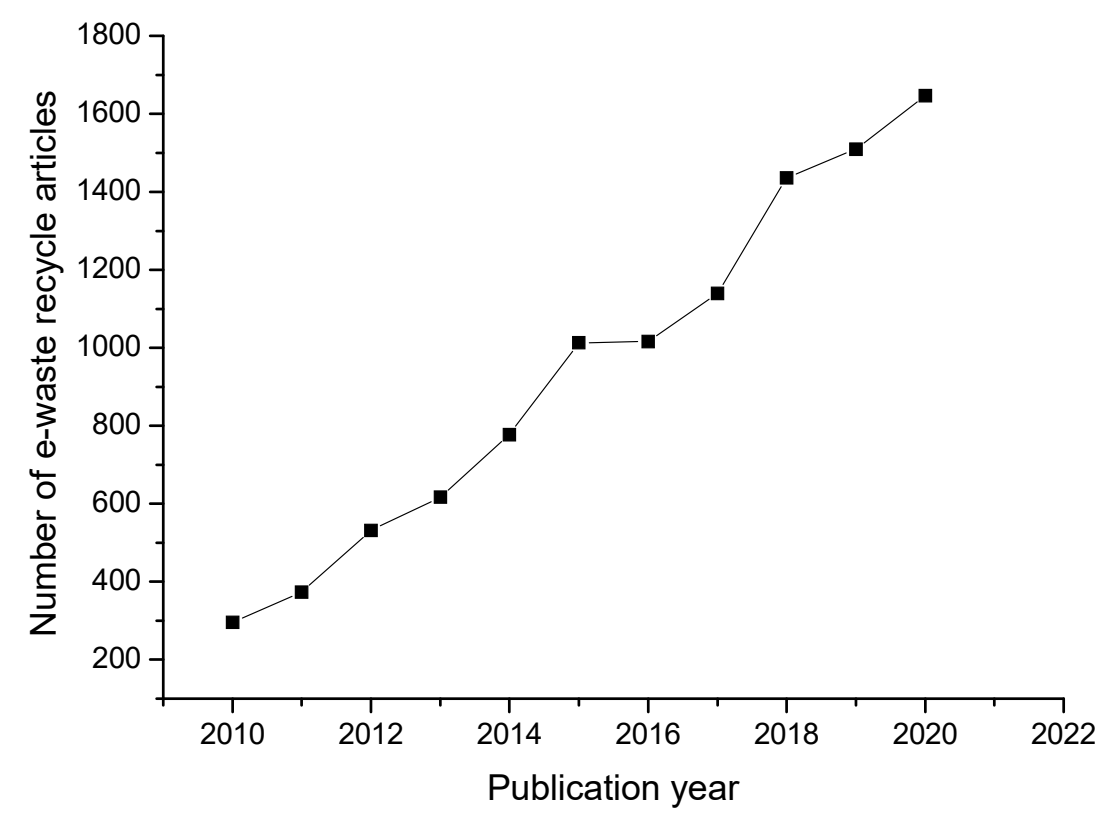

Figure 6. Number of articles about e-waste recycle between year's 2010 and 2020. These data were obtained from Brazilian Government Data Bank for scientific publications, between year's 2010 to 2020 (Capes, 2000)

The articles about contamination really represents the presence of e-waste chemical pollutants in the water (Wu et al., 2015), soil (Quan et al., 2015), plants (Wang et al., 2012), animals (Wu et al., 2016), and humans (Asante et al., 2012) near recycling areas (Figure 5). The articles about recycling (Figure 6) represents not only formal recycle, but mainly unconventional and dangerous recycle methods for environment. 
In the following pages we present the chemical contamination of environment and humans caused by the simple presence of e-waste in the environment, and by rude and nonconventional recycling. Utilizing Brazilian Government Search Site Capes (Capes, 2000), it was possible determine the approximate number of different kinds of contaminated samples by e-waste last twenty years (Figure 7). These data were obtained using keywords combinations such as: e-waste/soil, e-waste/river, e-waste/food, e-waste/animal, e-waste/vegetables, e-waste/humans, and others. This search reveal that water (water place + river + lake), soil, food, and humans are the most affected by e-waste.

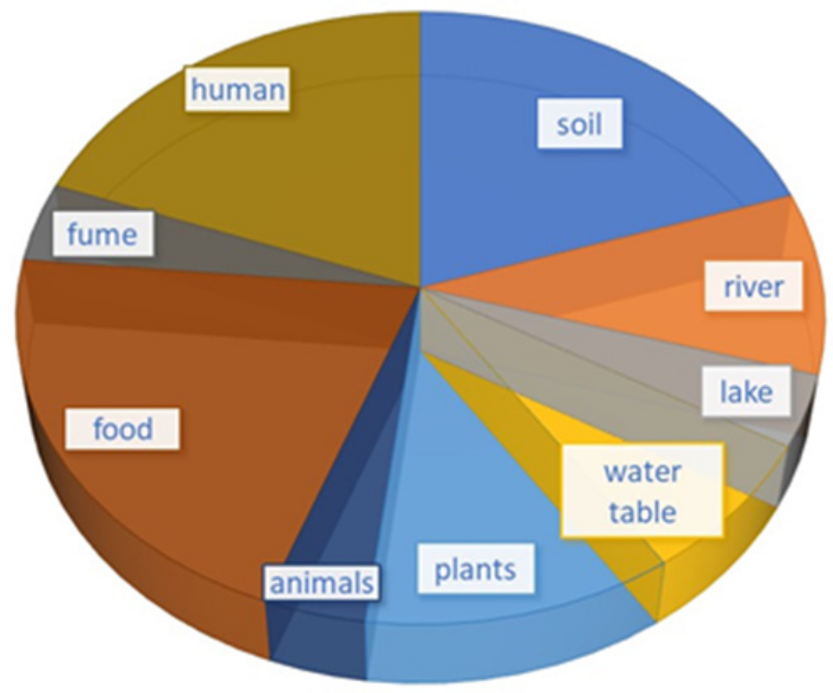

Figure 7. Different environmental samples contaminated by chemical pollutants from e-waste. These data were obtained from Brazilian Government Data Bank for scientific publications, between year's 2010 to 2020 (Capes, 2000)

\subsubsection{Soil}

China and U.S.A are the largest responsible by e-waste production of the world (Tiseo, 2021). However, some procedures for diminish the environment impact have been adopted. In China, for example, pollution control policies have been implemented since 2012. These policies diminished $\mathrm{Pb}$ present in the soil, but the high concentrations of $\mathrm{Cd}, \mathrm{Ni}, \mathrm{Cu}$, and $\mathrm{Zn}$ weren't impacted. The soil contamination in different locals of China occurs not only by activity of large recycling industries, but mainly by small e-waste dismantling workshops where the more rigorous pollution control would need. In these local cancer diseases occurrence increased, demonstrating that policies of pollution control need be more effective (Yang et al., 2020). In a study performed in some e-waste areas of Qingyuan (Guangdong Province, China), Chinese researchers detected largest metals concentrations in e-waste sites with active recycle than abandoned e-waste sites. The rude techniques to e-waste recycle utilizing, for example, acid lixiviation, cause increases in $\mathrm{Pb}, \mathrm{Cd}, \mathrm{Cu}$, and $\mathrm{Sb}$ concentrations in the soil. This kind of recycle activity represents serious risks for public health (Ádám et al., 2021).

In other Chinese study was evaluates total concentrations of some metals on surface, middle, and deep soils. The samples were collected from recycle areas of Guyu near a paddy field. The results of analyses showed that areas utilizing acid-leaching were severely contaminated by $\mathrm{Ni}, \mathrm{Cu}, \mathrm{Zn}, \mathrm{Cd}, \mathrm{Sn}, \mathrm{Sb}$, and $\mathrm{Pb}$. Was demonstrate that contamination occur especially on surfaces soils (Quan et al., 2015).

Recently, Thailand's researchers evaluated soil samples collected from five places e-waste recycling, and five place without recycling. All places studied are localized in the Buriram region, a Thailand's Province. The sample soils were analyzed for the toxic metal's contents utilizing an atomic absorption spectrophotometer. The results showed environmental risks and public health problems can be possible in this local. The toxic metals presence was mainly attributed to the high levels of $\mathrm{Cu}, \mathrm{As}, \mathrm{Cd}$, and $\mathrm{Pb}$ for the surface and subsurface soils. The concentrations of these chemical elements were higher in places e-waste recycling than no recycling places (Amphalop et al., 2020). The presence of this kind pollutant in environment is extremely dangerous because of the different disease resulting from toxic metals human exposure (Leston et al., 2010; Zeng et al., 2016; Waalkes, 
2020).

In a study realized at Chemistry's Department of Ambo University, Ethiopian researchers revealed surface dusts from electronic and electrical material maintenance workshops may to provoke chemical environmental contamination by toxic metals. In this study, surface dust samples were collected from electronic and electrical device maintenance workshops located in Ambo, Gedo, and Nekemte in Ethiopia. Results from analysis, utilizing the atomic absorption spectroscopy, revealed the presence of significative amount of $\mathrm{Pb}$ on surface dust samples (Getwachew et al., 2019). This study can be an alert for local population and health authorities. The danger is real and policies for diminish the dust from e-waste need to be immediately adopted.

In another study carried out in India, soil and dust samples were collected from e-waste recycling sectors in Chandigarh and Ludhiana (Punjab Province). The results obtained, through coupled plasma-optical emission spectrometer (ICP-OES), revealed high concentration of $\mathrm{Ba}, \mathrm{Cu}, \mathrm{Pb}$, and $\mathrm{Zn}$ in both sample (Singh et al., 2018).

Japanese and Vietnamese researchers collected garden's soil and floor dust samples from five households that living in an e-waste-processing area from village of Bui Dau (Hung Yen Province, Vietnam). Using an inductively coupled plasma mass spectrometer (ICP-MS), they estimated that garden soil and floor dust can be the main responsible to daily $\mathrm{Pb}$ intake by these households. These results were published in 2018 (Oguri et al., 2018).

In addition to regions in China, Ethiopia, India, Vietnam, and Thailand, Accra, in Ghana, is among the areas that has the biggest e-waste in the world. Tons of e-waste from United States and Europe are release in this African country. Approximately 200,000 people live daily with fume, water, soil, animals, and plants contaminated by chemical pollutants. The massive presence of the e-waste in Ghana is a classic example of the lack of human empathy. It is an example of the total lack of awareness about the planet we live on. It is a classic example in which thousands of innocents pay for the consuming and greedy habits of others (Daum et al., 2017). That's why investigations of several researchers are so important to alert the people and provide arguments for governments to adopt strict measures in activities involving e-waste. Therefore, several studies have been carried out using different types of samples from Ghana (Daum et al., 2017). For example, some Ghanaian researchers, from Institute for Environment and Sanitation Studies of Ghana's University, verified that soil and vegetation samples from Korle Lagoon area in Accra was contaminated with high metals concentrations, mainly soils samples near dumps containing e-waste. The Soil analysis showed that the $\mathrm{Pb}, \mathrm{Cd}$, and $\mathrm{Cu}$ concentrations exceeded their WHO/FAO thresholds for agricultural soils (Fosu-Mensah et al., 2017). These metals can contaminate water, animal, and vegetation. Photos present in the Environmental Justice Atlas show domestic animals drinking water and feeding in the e-waste area from Accra (Lepawsky and Akese 2015). Previously, in another study, soil/ash mixtures samples from Agbogbloshie e-waste recycling area in Accra, Ghana, were analyzed to verify the metals variation and distribution. Using an analytical methodology including a portable X-ray fluorescence spectrometer, researchers make it that human exposure to $\mathrm{Pb}, \mathrm{Cu}, \mathrm{As}$, and other metals is significative. According to these authors, the soil contamination is provoked mainly by ash from burning e-wastes (Itai et al., 2013).

However, not only metals are the responsible for soil contamination around e-waste (Abdelbasir et al., 2018). In a recent study, German and Nigerian researchers demonstrate that soil samples collected from Abuja's dumpsites in Nigeria, containing e-waste, are contaminated by polybrominated diphenyl ethers (PBDEs). In addition, PBDEs were found in samples such as: chicken eggs, bentgrass, spinach, tomatoes, pumpkin, and sweet potatoes (Oloruntoba et al., 2021). These compounds are utilized in electronic devices and other products as flame retardant.

In another investigation, PBDEs and Octa brominated diphenyl ether-79 (OctaBDE-79) were analyzed in sample soils from areas where waste electrical and electronic equipment plastics have been dumped and dismantled, over a long period, at different locations of Benin, Edo State, Nigeria. These soil sample were analyzed by gas chromatography-mass spectrometry (GC-MS). The results revealed that PBDEs concentration were no expressive, but OctaBDE-79 concentration was significative (Edene et al., 2020). PBDEs and its derivatives are known by its high toxicity (Viberg et al., 3006; Kaihan et al., 2020). Decabromodiphenyl ether (BDE-209), for example, can be provoke the negative effects such as: thyroid hormone disruption, neurobehavioral toxicity, and cancer (Li et al., 2014). BDE-209 and other toxic organic compounds were found in samples soil collected from four e-waste sites localized in Karachi City in the Pakistan (Iqbal et al., 2017).

Figures 8, 9 and 10 summarize research involving soils contaminated by pollutants generated by e-waste as well as their potential to contaminate humans. 


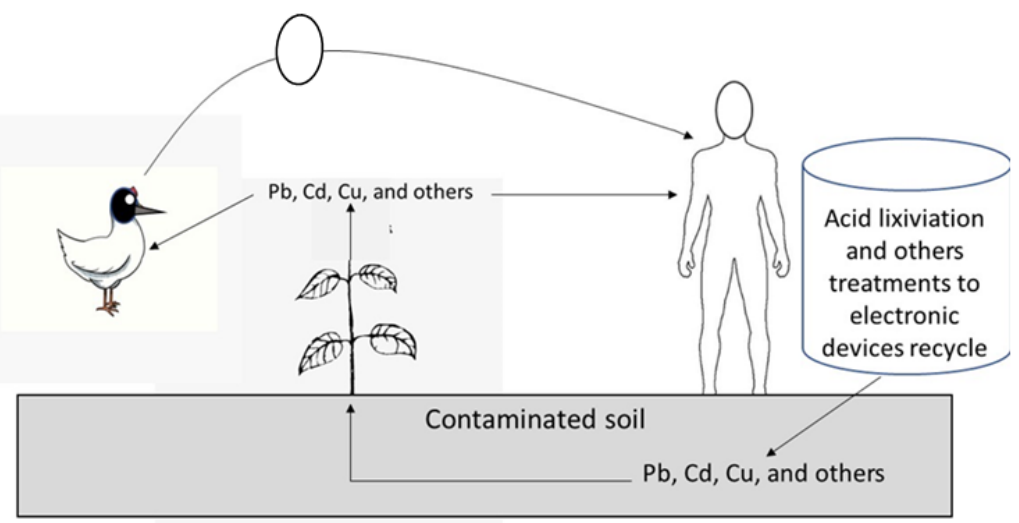

Figure 8. Chemical contamination of soil, plants, animals, eggs, and humans by rude activities to electronic devices recycle

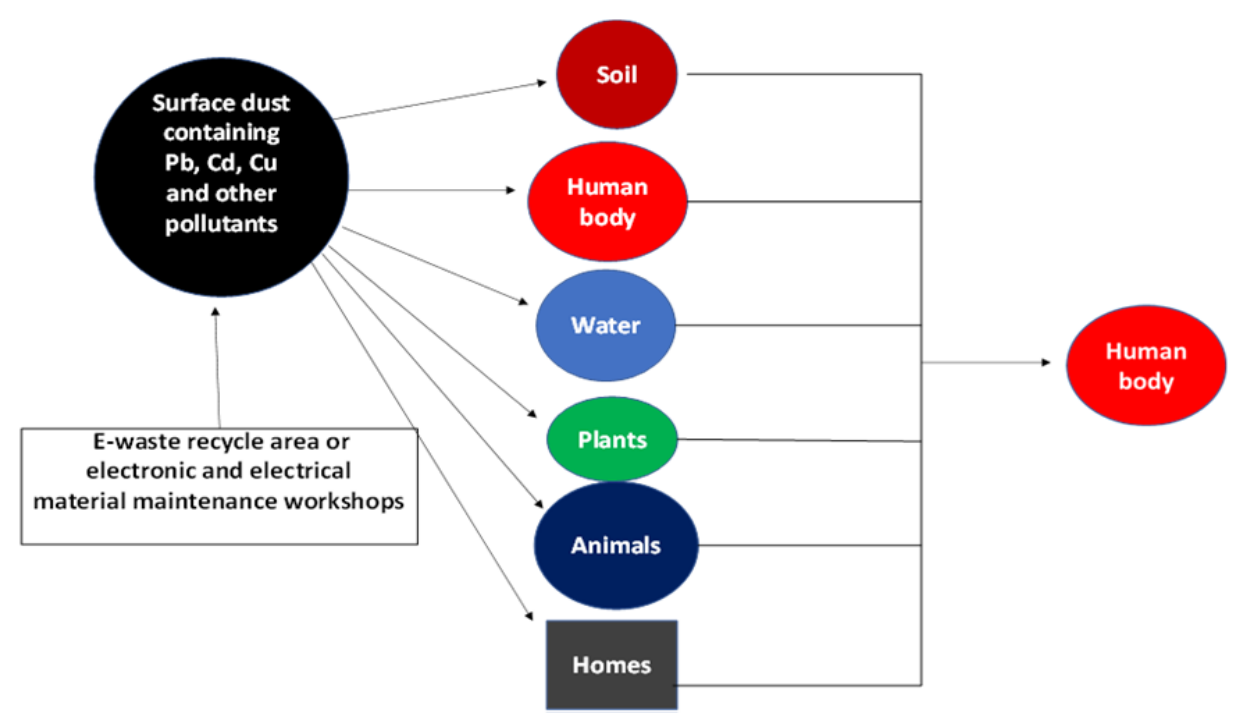

Figure 9. Surface dust distribution in the environment and its presence in the human body

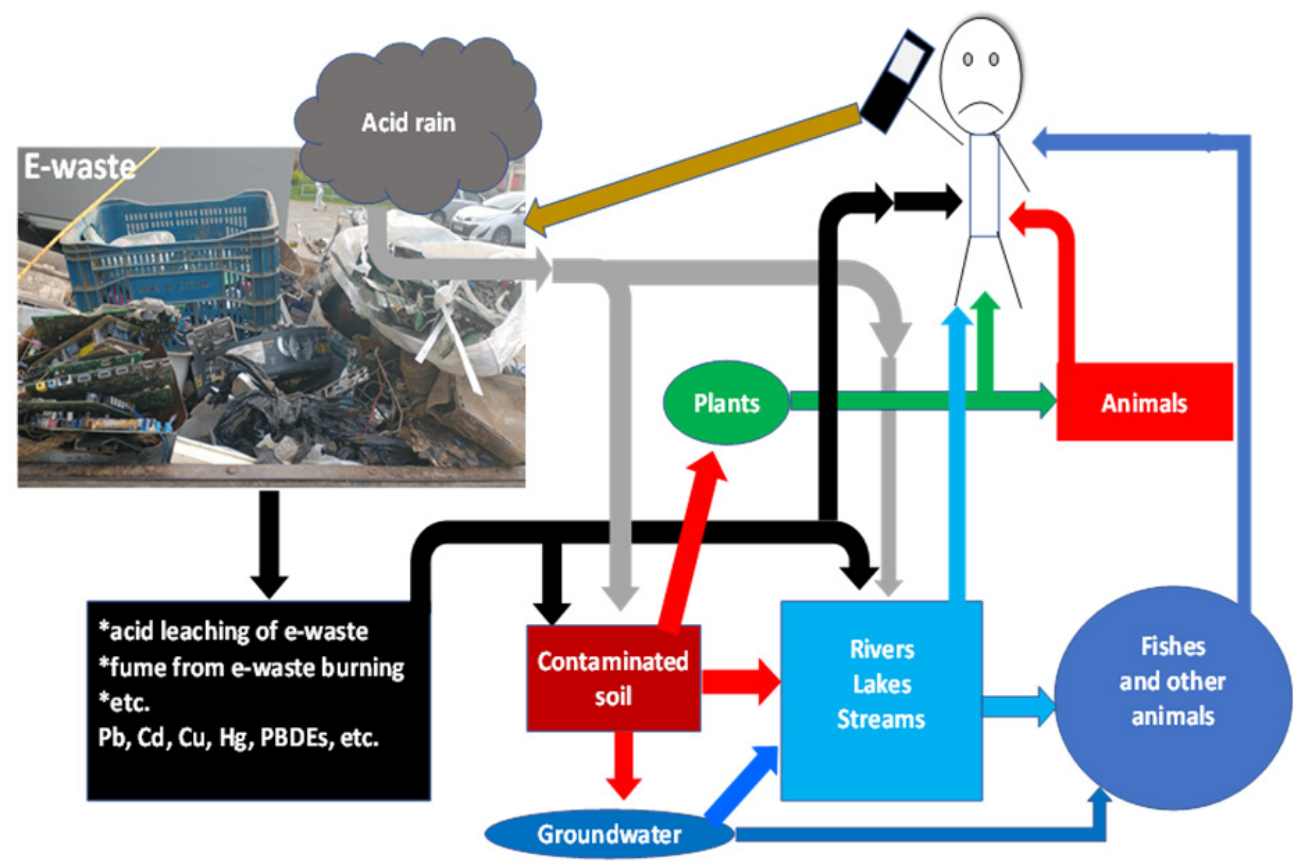

Figure 10. Human contamination by pollutants from e-waste dump 


\subsubsection{Water and Sediments}

Natural water sources such as: groundwater, streams, rivers, lakes, and others can be contaminated by chemical pollutants from e-waste, through different ways. In a review published in 2018, researchers focused on the Ganges River, India, contaminated by metals. This pollution is provoked by different sources. Among these sources, recycle activities in areas containing e-waste stand out. This review correlated the Ganges River pollution with different pathologies described in medical literature (Sankhla et al., 2018).

But these problems are not restricted to India. In various world places can be found natural water sources contaminated by e-waste pollutants. In a study published in 2007, researchers from the University of Hong Kong and Baptist University of Hong Kong, using ICP-MS, revealed that the Lianjiang and Nanyang rivers are contaminated by different metals. The samples of both rivers were collected near a region of Guiyu City, situated in Chaozhou region of Guangdong Province, South China. These rivers provide water supply for a large population. Were found metals such as: $\mathrm{As}, \mathrm{Cr}, \mathrm{Li}, \mathrm{Cd}, \mathrm{Cu}, \mathrm{Ni}$, and $\mathrm{Pb}$. This pollution was correlated with the numerous informal recycling sites of obsolete electronic devices near rivers. According to the authors, the contamination may have been caused by improper recycling such as acid leaching (Wong et al., 2007).

Several studies about chemical rivers pollution investigate different kinds of pollutants considering its presence in water as much as sediment. The physical chemistry characteristics of water as well as sediment may vary with $\mathrm{pH}$, salinity, oxygen demand, and other parameters. Furthermore, pollutants such as metals and toxic organic compounds, that have some affinity by sediments, can be release to water (Figure 11) due natural and anthropogenic factors. A study utilizing water and sediment samples from San Francisco River near Petrolina City (Pernambuco State, Brazil) concluded that the metals concentrations bioavailable in sediments show alarming values (Pereira et al., 2017). Inorganic pollutants can readily accumulate in benthic organisms and disseminate through the food chain (Amin et al., 2009).

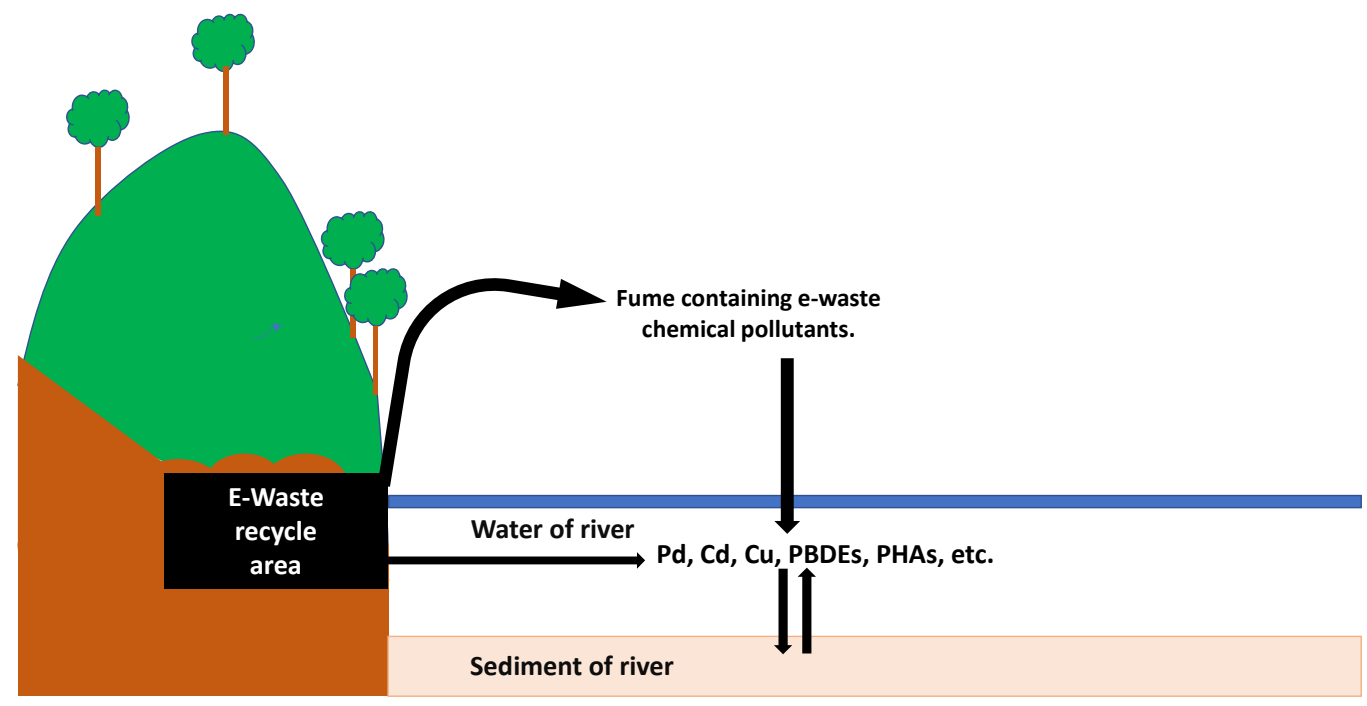

Figure 11. Natural water polluted by e-waste recycle activities and chemical pollutants present between water and sediments

In a research realized in Akure, Nigeria, was detect bioaccumulation of some toxic metals in the tissue of Oreochromis niloticus (tilapia) fish. The fishes were in contact with water samples contaminated with different mass of e-waste soil. After five days, some toxic metals were detected in the fish tissues using an atomic absorption spectrophotometer. It was observe the bioaccumulation of $\mathrm{Pb}, \mathrm{Cd}, \mathrm{Mn}, \mathrm{Co}, \mathrm{Ni}$, and other. The author concluded that e-waste can contaminate the soil in recycle area, wich represent a contamination risk to fishes in water near e-waste (Sanusi, 2016). In other Nigerian study study was investigated the possible contamination of water and soil samples from alaba, an International Electronics Market (AIEM) situated in Lagos. Utilizing an atomic absorption spectrometer, the researchers found metals such as $\mathrm{Pb}$ and $\mathrm{Cd}$ in soil and sources of water near Lagos. The main findings of this work were the significative levels of $\mathrm{Pb}$ and $\mathrm{Cd}$ in the groundwater (Otache et al., 2014).

In addition to Nigeria, Ghana also faces serious water contamination problems due chemical pollutants from e-waste. Researchers of Hohai University, Nanjing, China, wrote a review about the e-waste disposal effects on the 
aquatic environment in Accra. The large amount of electronic waste exposed near natural water sources represents a serious public health problem. Electronic devices dumps are constantly exposed to heavy rains. This situation causes water contamination by different pollutants that reach Odaw River and the Korle Lagoon. According to the authors, pollutants from e-waste limit the aquatic life diversity. Worrying amounts of metals such as: $\mathrm{Pb}, \mathrm{Cd}$, and $\mathrm{Cu}$ as well as organic pollutants were detected, by some authors, in water samples from these local (Huang et al., 2014). Chama et al. (2014), for example, collected Odaw River sediments samples from areas near e-waste recycle activities and from other without apparent activity. The data obtained using an atomic absorption spectrometer revealed that sediments collected from areas near e-waste with recycle activity contain metals in concentrations higher than sediments collected from areas without recycle activity. This kind of contamination is a worrying fact, because can provoke the toxic metals migration from groundwater to the plants, animals, and finally to the humans (Figure 10). So, what can you do to diminish the negative effects of this problem? Some simple projects that are occurring some places of the word maybe change this scenery in the future. In Mumbai, India, for example, a group of students walking around a tiny area of Powai Lake, for one day, collected e-waste such as: mobile phones, circuit boards, DVDs, and CDs. These materials were collected for disposal in an appropriate local. It was an important day about the practice environmental conscientization and a type of good example that should be followed by other schools in several countries (Earth, 2020).

\subsubsection{Vegetables and Animals}

Can we imagine that soil and water, polluted by e-waste, cause vegetable and animal contaminate? For sure this event is occurring. Several studies show the vegetables and animal chemical contamination by organic compounds and metals in areas near e-waste. In 2012, for example, different concentrations of hexabromocyclododecane (HBCD) isomers were found on terrestrial birds in the e-waste, urban, and rural areas near Pearl River Delta situated in South of China. The muscle's samples collected from birds living near e-waste area, situated in Qingyuan, demonstrated the presence of $\alpha$-HBCD in Pycnonotus sinensis, Lanius schach, and Copsychus saularis species. The presence of $\delta$-HBCD was detected only in Copsychus saularis (Sun et al., 2012). This is an important discovery due the HBCD toxicity. The electronic devices industry and other industrial sectors use HCBD as additive. The human exposure to the HBCD provokes endocrine disruption, neurotoxic effects, and alterations in reproductive and immune systems (Schecter et al., 2012).

In another study published in 2017 was investigated the presence of PHAs in fishes from Lianjiang River as well as its possible adverse effects in persons residents in Haimen Bay, near Lianjiang River estuary. This estuary is localized less than $30 \mathrm{~km}$ from Guiyu City (China), that contain one of the largest e-waste recycling sites of the world. The results showed the presence of worrying concentrations of PAHs in these fish samples. In Haimen Bay, PAHs represent a higher risk to cancer occurrence compared with areas less contaminated by them (Shi et al., 2017). It was possible correlate the cancer incidence with the number of persons contaminated by PAHs presents different fish species from Lianjiang River near Guiyu e-waste dumpsites. Through the Figure 12, we can imagine as occur the human contamination by PAHs from e-waste.

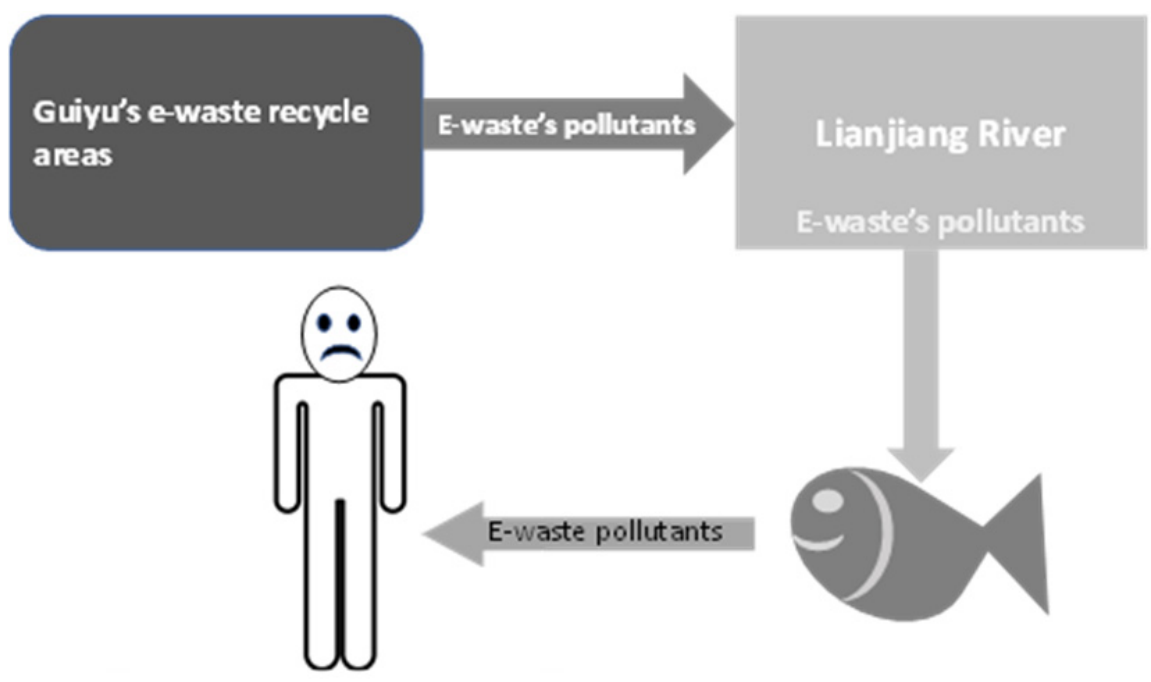

Figure 12. The PAHs's pathways from e-waste until humans thtough fishes 
Toxic organic compounds from e-waste really are an important pollutant class present in biological samples. The U.S. Environmental Protection Agency (EPA) warning to toxic effects provoked by these compounds. PBCs, for example, are known by its carcinogenic potential, besides its negative effects in immune, reproductive, nervous, and endocrine systems (EPA, 2021).

In a study using fishes, Chinese researchers collected 48 samples including 24 mud carp and 24 northern snakehead fish from a pond located in Qingyuan Count near an e-waste area. The results demonstrated the presence of halogenated organic pollutants (HOPs) in serum of both species. Moreover, the PCBs were the main HOPs found (Zeng et al., 2014). PCBs also were found in some species of fish, prawn, waterbird, frog, lizard, and watersnake in samples collected from a pond and its terrestrial area situated in Longtang Town, Qingyaun County at Guandong Province, China (Liu et al., 2018). This lake and its region are contaminated by chemical pollutants from an e-waste area where occur non-conventional recycle activities (Wu et al., 2008). In another study carried out far from Qingyaun, researchers of Ghana's University found PBDEs in different samples collected in an Agbogbloshie e-waste recycling site, including vegetables (Oteng-Ababio et al., 2014)

In addition to PBDEs, heavy metals also are frequently found in biological samples (Pereira et al., 2017) and its toxicity is very known (Balali-Mood et al., 2021). But despite being toxic in high concentrations, some metals are essential in small amounts (Zhang et al., 2018). For example, in a simple experiment for environmental education class realized in our laboratory, was possible to demonstrate the difference of copper effects in low and high concentrations in the growth of allium cepa root (ACR). It was demonstrated that occurs ACR growth inhibition in the solutions containing $200 \mathrm{mg} / \mathrm{g}$ copper, while a considerable ACR growth it was observed in aqueous solutions containing $0.2 \mathrm{mg} / \mathrm{L}$ copper (Figure 13). The cytogenetic analyze demonstrated that cell division it is more evident at copper low concentration than at high concentration (Figure 14).

\section{(A)}

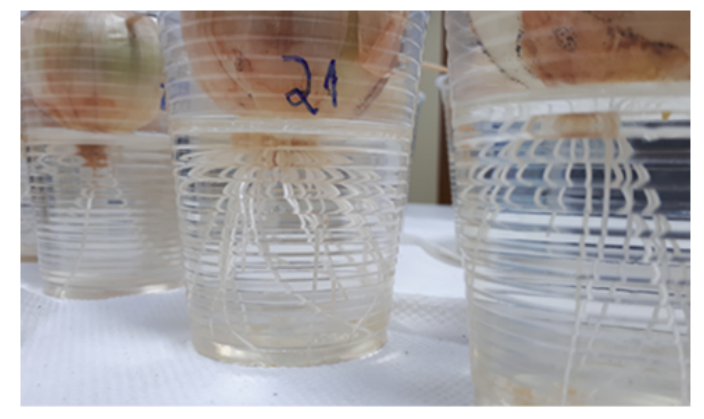

(B)

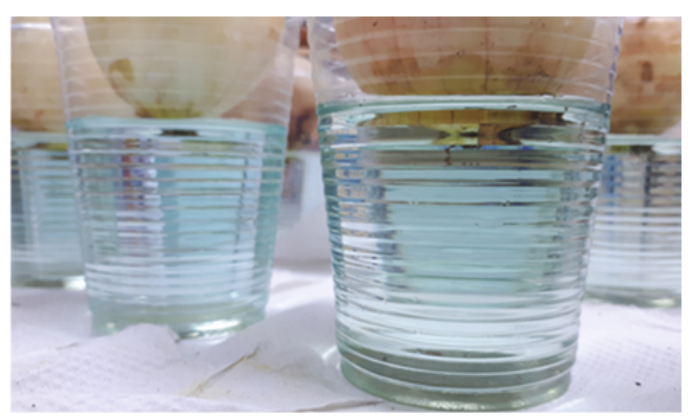

Figure 13. ACR growth in the solution containing $0.2 \mathrm{mg} / \mathrm{L}$ (A) and $200 \mathrm{mg} / \mathrm{g}$ copper (B). Experiment for environmental education class in our laboratory (Health Science Center, Federal University of Espírito Santo, Vitória-ES City, Brazil) 
(A)

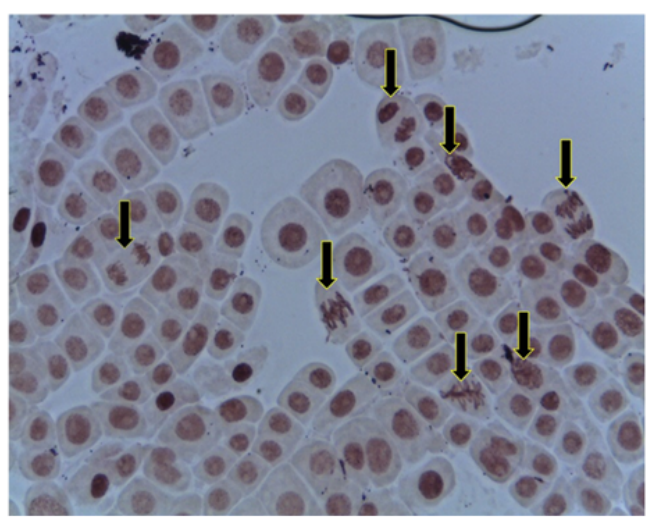

(B)

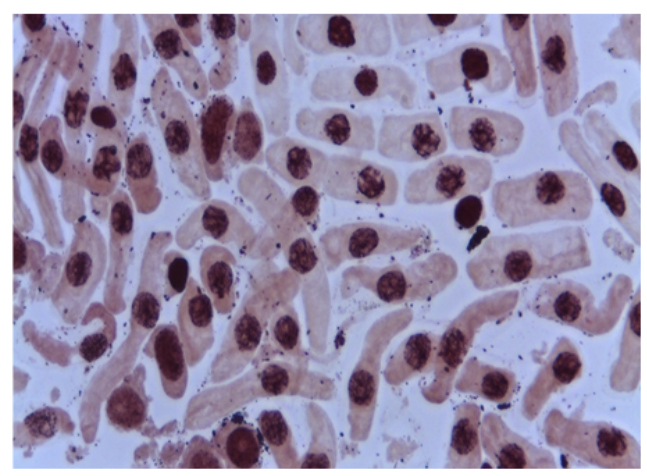

Figure 14. ACR cell division, indicated by arrows, in the solution containing $0.2 \mathrm{mg} / \mathrm{L}$ (A) and $200 \mathrm{mg} / \mathrm{g}$ copper (B), respectively. Experiment for environmental education class in our laboratory (Health Science Center, Federal University of Espírito Santo, Vitória-ES City, Brazil)

Heavy metals have been frequently found in vegetables samples collected near e-waste areas (Liu et al., 2021). In a study carried by Chinese researchers, the metals pollution in areas around of a primitive e-waste processing facility, Guangdong province of south China, was investigated. These researchers concluded that paddy fields and vegetable gardens in these areas were contaminated by metals such as: $\mathrm{Cu}, \mathrm{Pb}, \mathrm{Cd}$, and $\mathrm{Zn}$ (Luo et al., 2011). Posteriorly, in 2019, researchers of Guangzhou's University and Adelaide's University published an article about the rice plants contamination by chemical pollutants from an abandoned e-waste recycling site in Guiyu, south China. The analyzes for metals revealed considerable concentrations of Sb and Sn in rice plants (Wu et al., 2019). This contamination associated to the high rice consumption near e-waste areas can represent a real risk for human contamination (Figure 15). Despite the implementation regulatory laws and rise of sophisticated recycle technologies for much e-waste areas in China, the contamination risk of some food source by chemical pollutants continues (Fu et al., 2013). Studies realized between 2006 and 2010 by some Chinese researchers in Fengjiang Town, located in the southeast of Zhejiang Province, China confirm it. This local is an important e-waste recycling and rice crops. Among other findings, some authors demonstrated the dangerous chemical concentrations of some metals such as: $\mathrm{Cu}, \mathrm{Pb}, \mathrm{As}$, and $\mathrm{Cd}$ in rice samples. According to these authors is necessary stricter implementation of regulatory measures to controlling the release of metals from e-waste to the environment to diminish the risk of human contamination (Fu el al., 2013). 


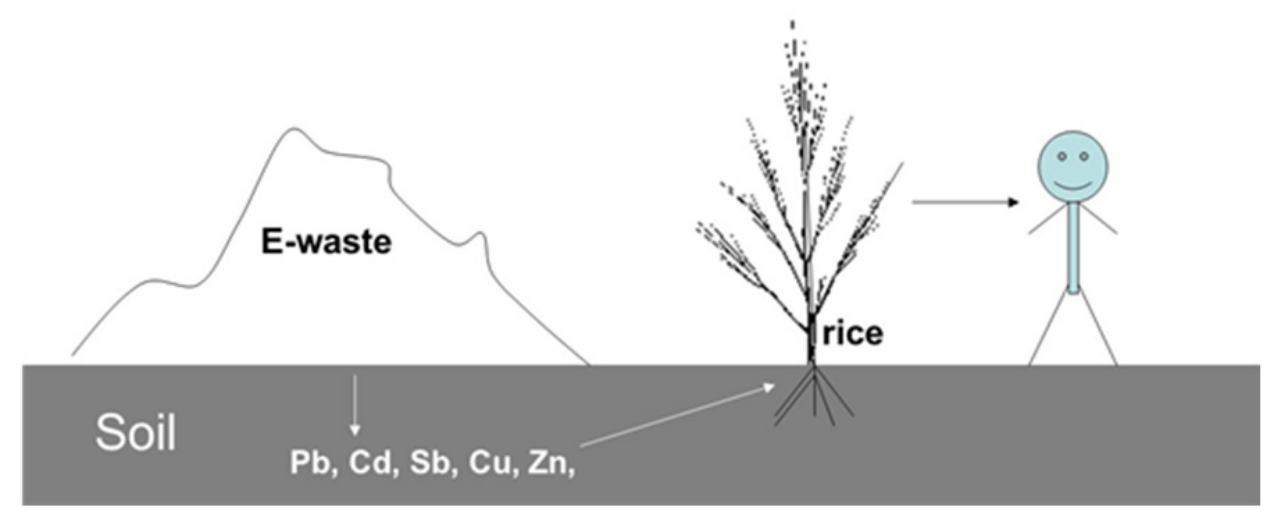

Figure 15. The high rice consumption near e-waste areas can represents a real risk for human contamination

Metals have been also can find in animals near e-waste areas. Recently was published a work about the capacity of Anabas testudineus specie fish to adapt at heavy metals and toxic organic compounds released in the aquatic environment by e-waste. Several physiological and biochemical responses were observed such as: oxidative stress, apoptosis, and increase in defensive responses, including increase in DNA repair, and oxidative stress response by endoplasmic reticulum (Zhang et al., 2019). This fish species is an important food source for many people living around water contaminated by e-waste. The nutrient profile of this fish (Paul et al., 2017) makes it an attractive food source and gives the false feeling that the natural water sources of these localities are not severely contaminated, since this species persists and reproduces (Zhang et al., 2019).

In other study involving samples fish was demonstrated that Channa striata species, from water around e-waste dumping area located on Khong Chai district (Kalasin province, Northeastern Thailand), were contaminated by $\mathrm{Cr}$, $\mathrm{Cd}$ and $\mathrm{Pb}$. These inorganic pollutants can induce chromosomal aberrations, serum biochemical parameter changes, and liver histopathological alterations. According to the authors, these observations can be as warning to human health conditions in contaminated locals (Phoonaploy et al., 2019).

\subsubsection{Humans}

Different kinds of pollutants are released every day in soils, air, rivers, lakes, and other water bodies by e-waste areas around the world. The environmental is contaminated from e-waste pollutants such as: plastic material, toxic metals, toxic organic compounds, and other (Hashmi \& Varma, 2019). The negative effects of these pollutants to humans occur mainly due chemical toxic mechanisms and probably by radiation emission from e-waste metals (Alayande et al., 2016). However, the chemical e-waste effects are more known than radiation effects. In 2016, for example, Nigerian researchers published an article (Alayande et al., 2016) about radiation measures in three major e-waste from AIEM in Ojos, Lagos State, Nigeria. These authors concluded that even with high amounts of toxic metals presence, the radiation wasn't shows serious risk for human health. The radiation, however, measured on the spot, could be an efficient method for metals amount variation in e-waste (Alayande et al., 2016).

Chemically, toxic metals pose a real threat to life. We need to remember that toxic metals such as: $\mathrm{Pb}, \mathrm{Cd}$, and $\mathrm{Hg}$ are practically incompatible with the life. There are several scientific publications that describe the deleterious effects on human body provoked by different metals (Kumar et al., 2018). Pb, for example, can provoke inhibition of heme biosynthesis resulting in low amounts of hemoglobin and severe anemia (Figure 16) (Lubran, 1980; Skerfving and Bergdahl, 2007). Cadmium interacts with biomolecules such as: DNA, RNA, proteins, and other. This heavy metal reacts with thiol groups damaging structures of different proteins (Figure 17), and consequently inhibiting their functions (Pereira et al., 1998). Furthermore, the chemical interaction between $\mathrm{Cd}$ and glutathione peptide (GSH) can provoke dangerous oxidative stress on cell and consequently its death (Orlando et al., 2021). 


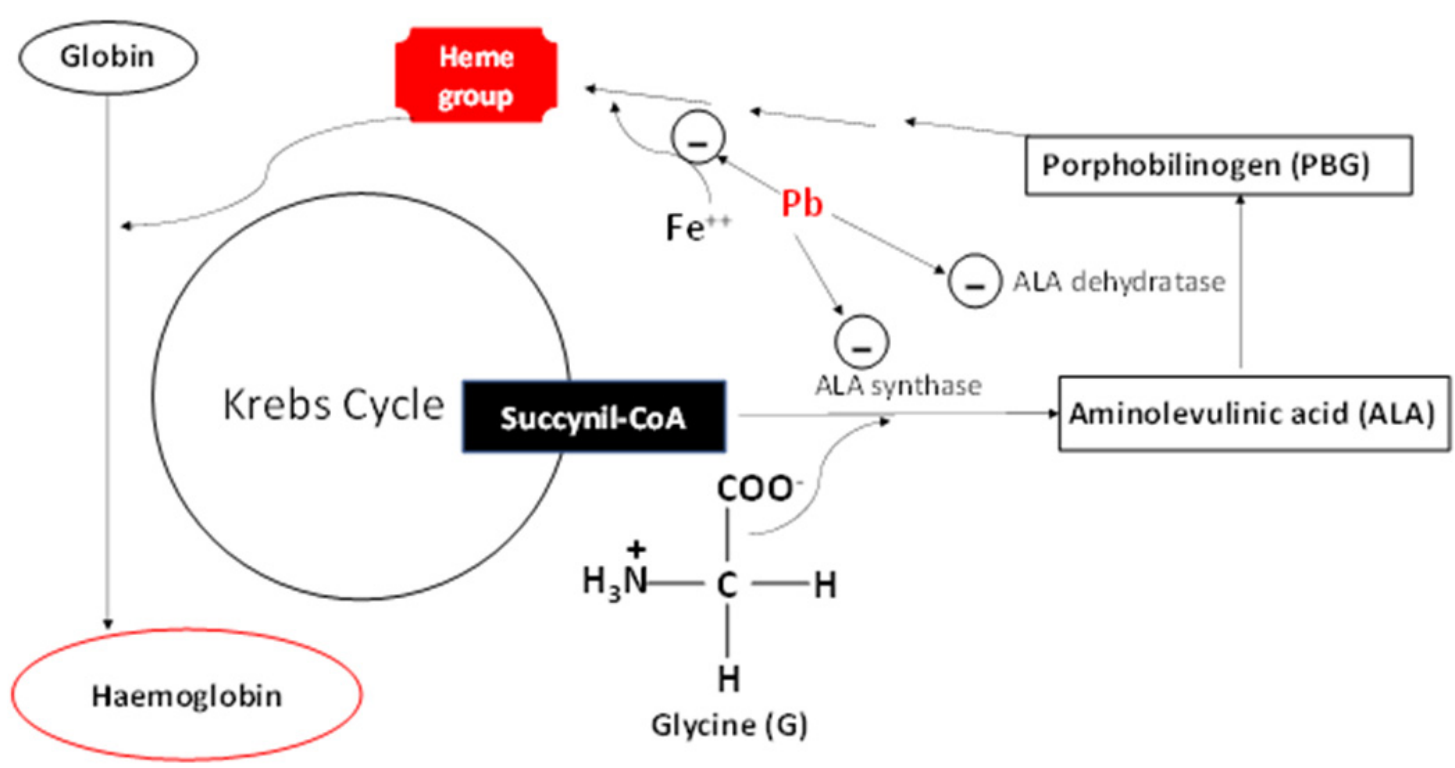

Figure 16. Some points of heme biosynthesis inhibited by $\mathrm{Pb}$. ALA synthase and ALA dehydratase inhibition, and iron addiction inhibition in porphyrin during heme synthesis, decreasing hemoglobin production. (Adapted from

Skerfving and Bergdahl, 2007)

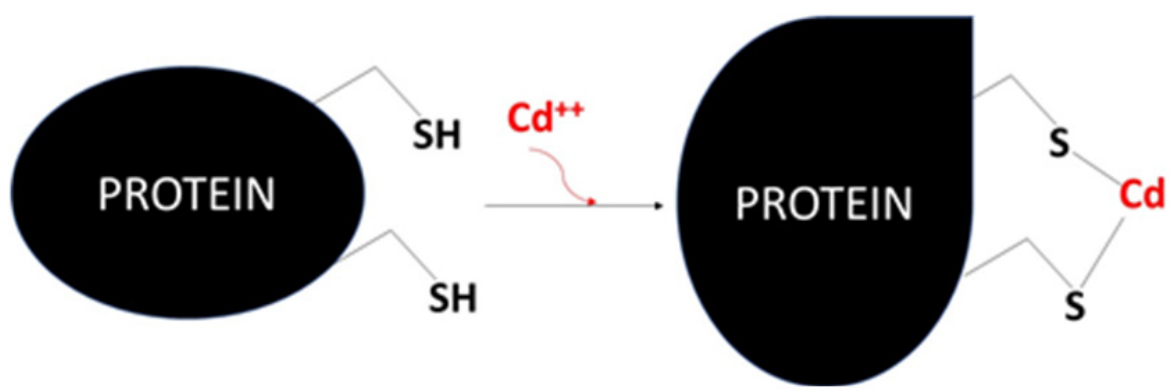

Figure 17. Cadmium reacts with thiol groups of proteins, damaging their structures and consequently inhibiting their functions.

The $\mathrm{Pb}$ concentration from some Chinese children's blood samples were analyzed using a graphite furnace atomic absorption after children immunization against to measles, mumps, and rubella (MMR). The study used blood samples from children who lived near e-waste areas in Guiyu and Haojiang, China. Was investigated the immune responsiveness for MMR. The $\mathrm{Pb}$ levels in the children's blood, that live in the areas near e-waste higher than $\mathrm{Pb}$ children's blood levels living in other farther area. Furthermore, the antibodies concentration against MMR were lower in children near e-waste areas. The authors concluded that these children exposition to the e-waste is associate to the low antibodies production against the MMR (Lyn et al., 2016).

In other Chinese work, researchers published a work about the correlation between blood contaminated with $\mathrm{Pb}$ and sex hormone levels in males exposed to e-waste dismantling area localized in Taizhou, Zhejiang Province. The results demonstrated that correlation between the male sex hormones and blood $\mathrm{Pb}$ concentration was significant. In some samples, the male follicle stimulating hormone and luteinizing hormone levels increase while the testosterone level reduced because $\mathrm{Pb}$ concentration growth (Yan et al., 2013).

Recently, Zhang et al. (2019) demonstrated that toxic metals urinary concentrations were significantly elevated in samples of human's urine obtained from e-waste dismantling areas in Qingyuan City, Guangdong province, China. In another work using blood samples from 267 exposed peoples to the e-waste area in Guyu, were found worrying $\mathrm{Pb}$ and $\mathrm{Cd}$ concentrations. These samples were compared with other blood samples obtained from 167 peoples no exposed to the e-waste area. $\mathrm{The} \mathrm{Pb}$ and $\mathrm{Cd}$ concentrations from exposed peoples were higher than no exposed peoples. All 267 participants were hospitalized, and their toxic metal levels were associated with elevated liver toxicity (Chen et al., 2019). 
Nigerian and English researchers investigated the $\mathrm{Pb}, \mathrm{Cu}, \mathrm{Mn}$, and $\mathrm{Zn}$ concentrations in blood samples of e-waste pickers in AIEM, Lagos, Nigeria. They collected 30 blood samples from adult males. These samples were analyzed using an atomic absorption spectrophotometer. High $\mathrm{Pb}$ and $\mathrm{Mn}$ concentrations were found (Popoola \& Popoola, 2019).

Between years 2010 and 2014, researchers of Department of Toxicology in Montevideo, Uruguay, south America, evaluated the $\mathrm{Pb}$ concentration in blood samples of children and teenagers exposed to e-waste material. $\mathrm{The} \mathrm{Pb}$ levels were considerably high in all samples. According to the authors, the manual gathering electronics process is the most common source of $\mathrm{Pb}$ exposure (Pascale et al., 2016).

In a review published by Zeng et al. (2016), the authors discussed about some children health problems provoked by toxic metals such as: $\mathrm{Pb}, \mathrm{Cd}, \mathrm{Hg}$, $\mathrm{As}$, and $\mathrm{Cu}$ from e-waste areas. Were mentioned health problems such as: lower lung function, hepatitis B, low antibody levels, higher prevalence of attention, deficit and hyperactivity disorders, and mutagenicity.

In a review published by Zeng et al. (2016), the authors discussed about some children health problems provoked by toxic metals such as: $\mathrm{Pb}, \mathrm{Cd}, \mathrm{Hg}, \mathrm{As}$, and $\mathrm{Cu}$ from e-waste areas. Were mentioned health problems such as: lower lung function, hepatitis B, low antibody levels, higher prevalence of attention, deficit and hyperactivity disorders, and mutagenicity. Two years later, results from an environmental investigation revealed the presence of high $\mathrm{Pb}, \mathrm{Cr}$, and $\mathrm{Zn}$ concentrations in dermal samples collected from adults and children living in e-waste areas situated in Chandigarh and Ludhiana, Punjab, India (Singh et al., 2018).

A study realized in Benin, demonstrated the fragility of the exposure of workers to the e-waste. Among the workers surveyed, few reported using any type of personal protective equipment (PPE). Most are completely exposed to different stages of recycling such as: dismantling, sorting, and incinerating. These workers reported several problems in respiratory system, heart, eyes, kidney, and cancer's cases that could be linked to their activity in e-waste areas (Houessionon et al., 2021). Another study, realized in Palestine, revealed a worrying scenario about the high childhood lymphoma occurrence and its link with e-waste burn sites. Another observation demonstrated strong evidence of correlation between e-waste recycle and cancer cases that occurs in West Bank (Davis and Garb 2019).

Sometimes the toxic metals from e-waste are not a problem for only the BRICs, CIVETS, and other emergent or poor countries. In developed countries, workers of formal recycling plants can be contaminated by chemical pollutants from e-waste. For example, in Sweden, researchers collected blood and urine samples from workers of two e-waste formal plants. The results showed high concentrations of $\mathrm{Cr}, \mathrm{Co}, \mathrm{In}, \mathrm{Pb}$, and $\mathrm{Hg}$ in both samples (Julander et al., 2014). Studies like this should be carried out in other developed countries.

In addition to metals, some toxic organic compounds from e-waste also occur in samples human (Siddiqi et al., 2003). In 2017 was published a work containing results from an evaluation realized to verify the presence of some chemical pollutants in dust's samples from e-waste recycling areas in south China. The PBDEs, PCBs, dechlorane plus, and decabromodiphenyl ethane concentrations were considered high and dangerous for human exposure (He et al., 2017). Evidence suggests that the PDBEs, for example, provoke several health problems such as: fatigue, reduced capacity to work, headache, endocrine disorders, hepatic tumors, thyroid problems, and dizziness (Siddiqi et al., 2003). Urine samples collected from workers living e-waste recycling areas, localized in an Accra suburb, showed high PHAs concentrations. The authors observed that a significative number of workers, with contaminated urine, presented cough and chest pain (Feldt et al., 2014).

Analyzing human breast milk samples obtained from some Vietnamese workers living in e-waste recycling sites from Trang Minh (suburb of Hai Phong city), Dong Mai, Bui Dau (Hung Yen province), and Hanoi, Japanese and Vietnamese researchers found significative amounts of PCBs, PBDEs, and HBCDs (Tue et al., 2010).

In a review published in 2011, the authors suggest that pregnant women and children living in e-waste areas are more vulnerable when constantly exposed at the risk of contamination by neurotoxicants agents such as: PBDEs, PCBs, and PHAs. These neurotoxic agents can provoke possible perturbations in fetus and child neurodevelopment (Chen et al., 2011).

\subsubsection{E-Waste and COVID-19}

The consumption of electronic devices such as: computers, TV sets, cell phones, and other electronic devices has considerably increased in COVID-19 pandemic times. This elevated consumption will cause an increase in disposal of electronic waste around world. This high consumption is so true that even the raw material sources for the electronic devices manufacture already show signs of supply limitations. Therefore, it can be suggested that there will not only an environmental impact, but also an increase in the prices of electronic devices as well as 
increase in technological inequality (Dutta et al., 2021).

The e-waste problems are not restricted to the health impact caused by its metals and toxic organic compounds such as: respiratory problems (Zeng et al., 2016), cancer (Siddiqi et al., 2003), hormonal dysfunction (Yan et al., 2013), and other. Some authors suggest that electronic material maybe transmit the COVID-19 virus when discarded in e-waste. The virus prevalence in plastic and metallic materials could be a real contamination form (Dutta et al., 2021). However, this is just a hypothesis. Furthermore, the main environmental problem generated by the people confinement at homes is the increase in electronic devices consumption and, consequently, their disposal in e-waste (Balde \& Kuehr, 2021).

In Brazil, several pickers are responsible for around 90\% e-waste recycling are therefore at greater risk of infection by the coronavirus. To ensure their survival, they cannot remain in lockdown, becoming more exposed to the virus both through social contact as well as through contact with e-waste probably contaminated by coronavirus (Ferraz, 2020).

Statistical data reveal that the first months of 2020 the drop in initial consumption of electronic products may have occurred in developing countries more than rich countries (Balde \& Kuehr, 2021). However, the lower consumption scenario in the initial confinement phase no represents the consumption in COVID-19 advance. The continuous use not only of computers and cell phones, but also of electronic games, TV sets, air conditioners, light bulbs could cause an increase in the disposal of e-waste and consequently an increase in environment negative effects. For example, after one year of pandemic, the online electronic devices sales increased $600 \%$ only Brazil (E-Commerce Brasil, 2021). Furthermore, environmental risks are not restricted to the exaggerated consumption of these products. A significant increase in mining activity to obtain raw material for the manufacture of electronic products represents another serious risk to the environment (Althaf \& Babbitt, 2021).

\section{Perspectives in COVID-19 Pandemic Times}

Only in Latin America, approximately 1.5 million lives were lost due COVID-19 pandemic. The governments took containment measures to avoid an even major catastrophe. In several Brazil and other countries places we could see empty streets, closed stores, public transport absence, industries with low operating capacity, unemployment, hunger, overwhelmed health system, stopped schools and colleges, cancelled flights, and other very atypical events. COVID-19 pandemic brought many uncertainties. But we can conclude that significant changes have taken. One of those was change in certain consumption habits. The significant increase in the electronic device's consumption is one of these habits.

Was the notable increase in electronics sale. These devices, with their programmed obsolescence, long before the pandemic were the main consumer items in modern society. However, in COVID-19 pandemic, they are main tools for work, study, leisure, and other needs. Billions of electronics tons are often improperly discarded into the environment every year. This amout, which was already worrying before the pandemic, could be significantly increased in the coming years. This will worsen if the pandemic persists, causing an increase in e-waste production and, consequently, more negative impacts in ecosystem. E-waste affects the environment though toxic metals, PHAs, PCBs, PBDEs, and other several pollutants that contaminate the soil, water, wildlife, domestic animals, eggs, milk, vegetable, humans and other. So, what can we do?

Governments, companies, research institutions, and society can take preventive measures to reduce environmental impacts during and after pandemic. For example, in an environmental education project proposed to the Government of the State of Espírito Santo (Brazil), our group intends to make high school youth aware of the real existence of this problem, and how it has become even more worrisome due to the COVID -19 pandemic. It will be shown how unconventional and clandestine recycling can be is just as dangerous as uncontrolled disposal. To raise awareness entire community school, a selective e-waste collection will be held at school. These students will go to all school places to explain the project proposal and request the receipt of electronic waste. After collection, the segregation of this waste will be carried out, and the choice devices that will be worked in the next stage of the project. The components of some electronic equipments such as: cell phones, computers, among others, will be disassembled and its chemical constitution identified from scientific literature. For demonstrate e-waste toxicity, we will use experiments to assess the effects of these waste in the growth of onion roots. Afterwards, the team (teachers and students) will propose methods to avoid excessive consumption, as well as safe recycling processes to reuse as much as possible this e-waste. Also, at the end of the project, students will develop an educational video about the subject. This video can help people's awareness toward to protection the Planet. Projects like this can be adopted by governments around the world. The environmental education is one of the alternatives to change behavior and reduces negative impacts in the environment. 


\section{Competing Interests Statement}

The authors declare that there are no competing or potential conflicts of interest.

\section{References}

ABC. (2006). La calidad de vida a nivel nacional. Retrieved Nov 12, 2021, from https://www.abc.com.py/

Abdelbasir, S. M., Hassan, S. S. M., Kamel, A. H., \& El-Nasr, R. S. (2018). Status of electronic waste recycling techniques: a review. Environmental Science and Pollution Research, 25(17), 16533-16547. https://doi.org/10.1007/s11356-018-2136-6

Ádám, B., Goen, T., Scheepers, P. T. J., Adliene, D., Batinic, B., Budnik, L. T., ... \& Wau, W. W. (2021). From inequitable to sustainable e-waste processing for reduction of impact on human health and the environment. Environmental Research, 194, 110728. https://doi.org/10.1016/j.envres.2021.110728

Alayande, S. O., Ofudje, A., Ezeh, G. C., Seglo, G., Omosalewa, A. O., \& Tobosun, I. (2016). Evaluation of radiation emission and elemental analysis in e-waste dumpsites. FUW Trends in Science \& Technology Journal, 1(1), 267-271.

Alsheyab, M. A. T. (2015). Potential recovery of precious metals from waste laptops in Jordan. Rare Metals, 34, 517-521. https://doi.org/10.1007/s12598-014-0337-9

Althaf, S., \& Babbitt, C. H. (2021). Disruption risks to material supply chains in the electronics sector. Resources, Conservation and Recycling, 167, 105248. https://doi.org/10.1016/j.resconrec.2020.105248

Amim, B., Smail, A., Arshad, A., Yap, C. H., \& Kamarudin, M. S. (2009). Anthropogenic impacts on heavy metal concentrations in the coastal sediments of Dumai, Indonesia. Environmental Monitoring and Assessment, 148, 291-305. https://doi.org/10.1007/s10661-008-0159-z

Amphalop, N., Suwantarat, N., Prueksasit, T., Yachusr, C., \& Srithongouthai, S. (2020). Ecological risk assessment of arsenic, cadmium, copper, and lead contamination in soil in e-waste separating household area, Buriram province, Thailand. Environmental Science and Pollution Research, 27, 44396-44411. https://doi.org/10.1007/s11356-020-10325-x

Asante, K. A., Agusa, T., Biney, C. A., Agyecum, W. A., Bello, M., Otsuka, M., Itai, T., ... \& Tanabe, S. (2012). Multi-trace element levels and arsenic speciation in urine of e-waste recycling workers from Agbogbloshie, Accra in Ghana. Science of the Total Environment, 424, 63-73. https://doi.org/10.1016/j.scitotenv.2012.02.072

Balali-Mood, M., Naseri, K., Tahergorabi, Z., Khazdair, M. R., \& Sadeghi, M. (2021). Toxic mechanisms of five heavy metals: mercury, lead, chromium, cadmium, and arsenic. Frontiers in Pharmacology, 12, 643972, 1-19. https://doi.org/10.3389/fphar.2021.643972

Balde, C. P., Wang, F., Kuehr, R., \& Huisman, J. (2015). The global e-waste monitor - 2014, United Nations University, IAS - SCYCLE, Bonn, Germany.

Balde, C. P., \& Kuehr, R. (2021). Impact of the COVID-19 Pandemic on E-waste in the First Three Quarters of 2020. United Nations University (UNU)/United Nations Institute for Training and Research (UNITAR) co-hosting the SCYCLE Programme, Bonn (Germany).

Bazilian, S. (2020). E-waste in developing countries: treasure to trash? Borgen Magazine. Retrieve Mar 10, 2021, from https://www.borgenmagazine.com/e-waste-developing-countries/

Bhattacharya, A. (2017). For every person in Hong Kong, there are 48 pounds of electronic waste per year. Quartz. Retrieve May 8, 2021, from https://qz.com/895504/asia-has-a-growing-e-waste-problem-and-hong-kong-is-its-hidden-villain/

Borthakur, A., \& Singh, P. (2012). Electronic waste in India: Problems and policies. International Journal of Environmental Sciences, 3(1), 353-362. doi:10.6088/ijes.2012030131033

Bradley, L. (2014). E-waste in developing countries endangers environment, locals.: U.S.News. Retrieve May 10, 2021, from https://www.usnews.com/news/articles/2014/08/01/e-waste-in-developing-countries-endangersenvironment-locals

Buzuev, V. (2015). ToxiCity. The story of Agbobloshie, a graveyard for electronics and people. RTA Documentary Channel. Retrieved Apr 19, 2021, from https://rtd.rt.com/films/toxicity/

Capes. (2000). Retrieved May 17, 2021, from https://www.gov.br/capes/pt-br 
Chama, M. A., Amankwa, E. F., \& Oteng-Ababio, M. (2014). Trace metal levels of the Odaw River sediments at the Agbogbloshie e-waste recycling site. Journal of Science and Technology, 34(1), 1-8. https://doi.org/10.4314/just.v34i1.1

Chen, A., Dietrich, K.N., Huo, X., \& Ho, Shuk-mei. (2011). Developmental neurotoxicants in e-waste: an emerging health concern. Environmental Health Perspectives, 119(4), 431-438. https://doi.org/10.1289/ehp.1002452

Chen, Y., Xu, X., Zeng, Z., Lin, X., Qin, Q., \& Huo, X. (2019). Blood lead and cadmium levels associated with hematological and hepatic functions in patients from an e-waste-polluted área. Chemosphere, 220, 531-538. https://doi.org/10.1016/j.chemosphere.2018.12.129

Cruz-Sotelo, S. E., Ojeda-Benitez, S., Sesma, J. J., Velazquez-Victorica, K. I., Santillan-Soto, N., Garcia-Cueto, O. R., ... \& Alcantara, C. (2017). E-Waste Supply chain in Mexico: challenges and opportunities for sustainable management. Sustainability, 9(4), 503-520. https://doi.org/10.3390/su9040503

Daum, K., Stoler, J., \& Grant, R. J. (2017). Toward a more sustainable trajectory for e-waste policy: a review of a decade of e-waste research in Accra, Ghana. International Journal of Environmental Research and Public Health, 14(2), 135-152. https://doi.org/10.3390/ijerph14020135

Davis, John-Michael, \& Garb, Y. (2019). A strong spatial association between e-waste burn sites and childhood lymphoma in the West Bank, Palestine. International Journal of Cancer, 144, 470-475. https://doi.org/10.1002/ijc.31902

Dutta, D., Arya, S., Kumar, S., \& Lichtfouse, E. (2021). Electronic waste pollution and the COVID-19 pandemic. Environmental Chemistry Letters. https://doi.org/10.1007/s10311-021-01286-9

E-Commerce Brasil. (2021). Com um ano de pandemia, venda online de eletrônicos aumenta $600 \%$ no Brasil. Retrieved Nov 11, 2021, from https://www.ecommercebrasil.com.br/noticias/venda-online-eletronicos-aumenta-brasil-coronavirus/

Earth 5R. (2020) E-waste found around Powai Lake. Sustainable Development Goals. Retrieved on Jul 3, 2021, from https://earth5r.org/e-waste-found-around-powai-lake/

Edene, O. A., Edene, S. O., Eigbike, C. O., Onaiwu, D. J., Olorunfemi, D. I., \& Onoagbe, I. O. (2020). Assessment and quantification of polybrominated diphenyl ethers (PBDEs) in soils of e-waste dumpsites in Benin City, Nigéria. African Scientist, 21(1), 245-252.

EPA: United States Environmental Protection Agency. (2021). Learn about Polychlorinated Biphenyls (PCBs). Health effects of PCBs. Retrieved Jul 12, 2021, from https://www.epa.gov/pcbs/learn-about-polychlorinated-biphenyls-pcbs

Feldt, T., Fobil, J.N., Wittsiepe, J., Wilhelm, M., Till, H., Zoufaly, A., Burchard, G., \& Göen, T. (2014). High levels of PAH-metabolites in urine of e-waste recycling workers from Agbogbloshie, Ghana. Science of the Total Environment, 466-467, 369-376. https://doi.org/10.1016/j.scitotenv.2013.06.097

Ferraz, C. (2020). Waste pickers responsible for 90\% of Brazil's recycling at greater risk of coronavírus. RioOnWatc Community Reporting on Rio.Retrieved Nov 27, 2021, from https://rioonwatch.org/?p=59928

Fosu-Mensah, B. Y., Addae, E., Yirenya-Tawiah, D., \& Nyame, F. (2017). Heavy metals concentration and distribution in soils and vegetation at Korle Lagoon area in Accra, Ghana. Cogent Environmental Science, 3, Article ID: 1405877. https://doi.org/10.1080/23311843.2017.1405887

Fu, J., Zhang, A., Wang, T., Qu, G., Shao, J., Yuan, B., Wang, Y., \& Jiang, G. (2013). Influence of e-waste dismantling and its regulations: temporal trend, spatial distribution of heavy metals in rice grains, and its potential health risk. Environmental Science \& Technology, 47, 7437-7445. https://doi.org/10.1021/es304903b

Getwachew, B., Amde, M., \& Danno, B. L. (2019). Level of selected heavy metals in surface dust collected from electronic and electrical material maintenance shops in selected Western Oromia towns, Ethiopia. Environmental Science and Pollution Research, 26, 18593-1860. https://doi.org/10.1007/s11356-019-05018-z

Global E-Waste Statistics Partnership. (2019). Retrieved Nov 12, 2021, from https://globalewaste.org/

Global E-Waste Statistics Partnership. (2019). Brazil: Data collected in the year 2019. Retrieved May 2, 2021 from https://globalewaste.org/statistics/country/brazil/2019/ 
Global E-Waste Statistics Partnership. (2019). Ghana: Data collected in the year 2019. Retrieved Apr 17, 2021 from https://globalewaste.org/statistics/country/ghana/2019/

Global E-Waste Statistics Partnership. (2019) Paraguay: Data collected in year 2019. Retrieved May 2, 2021 from https://globalewaste.org/statistics/country/paraguay/2019/

Hameed, H. B., Ali, Y., \& Petrillo, A. (2020). Environmental risk assessment of E-waste in developing countries by using the modified-SIRA method. Science of The Total Environment, 733, 138525-138537. https://doi.org/10.1016/j.scitotenv.2020.138525

Hashmi, M. Z., \& Varma, A. (2019). Electronic waste pollution: environmental occurrence and treatment technologies. Soil Biology, 57, 355. Springer International Publishing. https://doi.org/10.1007/978-3-030-26615-8

Han, Y., Tang, Z., Sun, J., Xing, Zang, M., \& Cheng, J. (2019). Heavy metals in soil contaminated through e-waste processing activities in a recycling area: Implications for risk management. Process Safety and Environmental Protection, 125, 189-196. https://doi.org/10.1016/j.psep.2019.03.020

He, Chun-Tao., Zheng, Xiao-Bo., Yan, X., Zheng, J., Wang, Mei-Huan., Tan, X., Quiao, L., ... \& Mai, Bi-Xian. (2017). Organic contaminants and heavy metals in indoor dust from e-waste recycling, rural, and urban areas in South China: Spatial characteristics and implications for human exposure. Ecotoxicology and Environmental Safety, 140, 109-115. https://doi.org/10.1016/j.ecoenv.2017.02.041

Houessionon, M. G. K., Basu, N., Bouland, C., Kedote, N. M., Fayomi, B., Fobil, N. J., \& Ouendo, Edgard-Marius. (2021). Knowledge, practices, and environmental and occupational health risks associated with electronic waste recycling in Cotonou, Benin. Occupational Diseases and Environmental Medicine, 9, 33-48. https://doi.org/10.1289/isee.2020.virtual.P-0615

Huang, J., Nkrumah, N. P., Anim, D. O., \& Mensah, E. (2014). E-waste disposal effects on the aquatic environment: Accra, Ghana. Reviews of Environmental Contamination and Toxicology, 229, 19-34. https://doi.org/10.1007/978-3-319-03777-6_2

Iqbal, M., Syed, J. H., Breivik, K., Chaudhry, M. J. I., Li, J., Zhang, G., \& Malik, R. N. (2017). E-waste driven pollution in Pakistan: The first evidence of environmental and human exposure to flame retardants (FRs) in Karachi City. Environmental Science \& Technology, 51, 13895-13905. https://doi.org/10.1021/acs.est.7b03159

Itai, T., Otsuka, M., Asante, K.A., Muto, M., Opoku-Ankomah, Y., Ansa-Asare, O. D., \& Tanabe, S. (2013). Variation and distribution of metals and metalloids in soil/ash mixtures from Agbogbloshie e-waste recycling site in Accra, Ghana. Science of the Total Environment, 470-471, 707-716. https://doi.org/10.1016/j.scitotenv.2013.10.037

Julander, A., Lundgren, L., Skare, L., Grander, M., Palm, B., Vahter, M., \& Liden, C. (2014). Formal recycling of e-waste leads to increased exposure to toxic metals: an occupational exposure study from Sweden. Environment International, 73, 243-251. https://doi.org/10.1016/j.envint.2014.07.006

Kaihan, C., Qingbin, S., Wenyi, Y., Jujun, R., Huabo, D., Ying, L., \& Jinhui, L. (2020). Human exposure to PBDEs in e-waste areas: a review. Environmental Pollution, 267, 115634. https://doi.org/10.1016/j.envpol.2020.115634

Kitila, A. W., \& Woldemikael, S. M. (2019). Waste electrical and electronic equipment management in the educational institutions and governmental sector offices of Addis Ababa, Ethiopia. Waste Management, 85, 30-41. https://doi.org/10.1016/j.wasman.2018.12.007

Kitila, A. W., \& Woldemikael, S. M. (2021). Electronic waste management in Addis Ababa: The case of Bole and Nefas Silk Lafto sub-cities. African Journal of Science, Technology, Innovation and Development, 13(2), 235-246. https://doi.org/10.1080/20421338.2020.1712014

Kumar, A., Singh, N., Pandey, R., Gupta, V. K., \& Sharma, B. (2018). Biochemical and Molecular Targets of Heavy Metals and Their Actions. In: Rai M., Ingle A., Medici S. (eds), Biomedical Applications of Metals. Springer, Cham. 2018. https://doi.org/10.1007/978-3-319-74814-6_14

Lecher, C. (2019). American trash: How an e-waste sting uncovered a shocking betrayal. The Verge Science. Retrieved on May 5, 2021, from https://www.theverge.com/2019/12/4/20992240/e-waste-recycling-electronic-basel-convention-crime-total-r eclaim-fraud 
Lepawsky, J., \& Akese, G. (2017). Sweeping Away Agbobgloshie. Again. Discard Studies. Used as source's material for: "Korle Lagoon Restoration Project and displacement from Accra's Old Fadama Slum, Ghana". Environmental Justice Atlas. Retrieved on Jun 3, 2021, from https://ejatlas.org/conflict/accras-agbogbloshie-electronic-waste-dump

Leston, J.G., Mendez, J., Pasaro, E., \& Laffon, B. (2010). Genotoxic effects of lead: an updated review. Environmental International, 36(6), 623-636. https://doi.org/10.1016/j.envint.2010.04.011

Li, M., Liu, Z., Gu, L., Yin, R., Li, H., Zhang, X., Cao, T., \& Jiang, C. (2014). Toxic effects of decabromodiphenyl ether (BDE-209) on human embryonic kidney cells. Frontiers in Genetics, 5(118), 1-7. https://doi.org/10.3389/fgene.2014.00118

Liu, Y., Luo, X. J., Huang, L. Q., Tao, L., Zeng, Y. H., \& Mai, B. X. (2018). Halogenated organic pollutants in aquatic, amphibious, and terrestrial organisms from an e-waste site: habitat-dependent accumulation and maternal transfer in watersnake. Environmental Pollution, 241, 1063-1070. https://doi.org/10.1016/j.envpol.2018.06.038

Liu, X., Gu, S., Yang, S., Deng, J., \& Xu, J. (2021). Heavy metals in soil-vegetable system around E-waste site and the health risk assessment. Science of the Total Environment, 779, 146438. https://doi.org/10.1016/j.scitotenv.2021.146438

Lopes, B. (2018). Brazil is the 5th country in smartphone usage. PagBrasil. Retrieved on May 8, 2021, from https://www.pagbrasil.com/insights/smartphone-usage-in-brazil/

Lubran, M. M. (1980). Lead toxicity and heme biosynthesis. Annals of Clinical \& Laboratory Science, 10(5), 402-413.

Luo, C., Liu, C., Wang, Y., Liu, X., Li, F., Zhang, G., \& Xiangdong, Li. (2011). Heavy metal contamination in soils and vegetables near an e-waste processing site, South China. Journal of Hazardous Materials, 186(1), 481-490. https://doi.org/10.1016/j.jhazmat.2010.11.024

Lyn, Y., Xu, X., Dai, Y., Zhang, Y., Li, W., \& Huo, X. (2016). Considerable decrease of antibody titers against measles, mumps, and rubella in preschool children from an e-waste recycling area. Science of the Total Environment, 573, 760-766. https://doi.org/10.1016/j.scitotenv.2016.08.182

Maphosa, V., Maphosa, M., \& Tan, A.W.K. (2020). E-waste management in Sub-Saharan Africa: a systematic $\begin{array}{lllll}\text { literature review. Cogent Business \& } & \text { Management, } & 7(1), & 1-19 .\end{array}$ https://doi.org/10.1080/23311975.2020.1814503

Minter, A. (2016). The burning truth behind an e-waste dump in Africa: Ending the toxic smoke rising from an iconic dump in Ghana will take more than curbing Western waste. Smithsonian Magazine. Retrieved on May 9, 2021, from https://www.smithsonianmag.com/science-nature/burning-truth-behind-e-waste-dump-africa-180957597/

Nnorom, I. C., \& Osibanjo, O. (2008). Electronic waste (e-waste): material flows and management practices in Nigeria. Waste Management, 28(8), 1472-1479. https://doi.org/10.1016/j.wasman.2007.06.012

Oguri, T., Suzuki, G., Matsukami, H., Uchida, N., Tue, N. M., Tuyen, L. H., ... \& Takigami, H. (2018). Exposure assessment of heavy metals in an e-waste processing area in northern Vietnam. Science of the Total Environment, 621, 1115-1123. https://doi.org/10.1016/j.scitotenv.2017.10.115

Oloruntoba, K., Sindiku, O., Osibanjo, O., Herold, C., \& Weber, R. (2021). Polybrominated diphenyl ethers (PBDEs) concentrations in soil and plants around municipal dumpsites in Abuja, Nigeria. Environmental Pollution, 277, 116794-116803. https://doi.org/10.1016/j.envpol.2021.116794

Orlando, P., Silvestri, S., Cirilli, I., Marcheggiani, F., Falcione, G., Cantarini, M., Galeazzi, R., \& Tiano, L. (2021). Involvement of different hemoprotein thiol groups of Oncorhynchus mykiss in cadmium toxicity. Journal of Trace Elements in Medicine and Biology, 66, 126746. https://doi.org/10.1016/j.jtemb.2021.126746

Otache, M. Y., Musa, J. J., Animashaum, I. M., \& Oji, D. M. (2014). Evaluation of the effects of electronic waste on topsoil and groundwater. International Journal of Science, Engineering and Technology Research, 3(12), 3469-3473.

Oteng-Ababio, M., Chama, M. A., \& Amankwaa, E. F. (2014). Qualitative analysis of the presence of PBDE in ashes, soils and vegetables from Agbogbloshie e-waste recycling site. Journal of Environmental Research and Management, 5(4), 71-80. 
Pascale, A., Sosa, A., Bares, C., Battocletti, A., Moll, M.J., Pose, D., Laborde, A., Gonzáles, H., \& Feola, G. (2016). E-Waste informal recycling: an emerging source of lead exposure in South America. Annals of Global Health, 82(1), 197-201. http://doi.org/10.1016/j.aogh.2016.01.016

Paul, B. N., Chanda, S., Bhowmick, S., Sridhar, N., Sha, G.S., \& Giri, S. S. (2017). Nutrient profile of indian climbing perch, Anabas testudineus. SAARC Journal of Agriculture, 15(1), 99-109. https://doi.org/10.3329/sja.v15i1.33156

Pereira, M. E. F., Yakushin, S., \& Cohen, G. (1998). Disruption of the intracellular sulfhydryl homeostasis by cadmium-induced oxidative stress leads to protein thiolation and ubiquitination in neuronal cells. The Journal of Biological Chemistry, 273(21), 12703-12709. https://doi.org/10.1074/jbc.273.21.12703

Pereira, M. G., Souza, C. L. M., Sachdev, R. D. L., Santos, A. V. D., Pinto, P. A. D. C., Souza, L. A.,... \& Ribeiro, A. V. F. N. (2017). Heavy metals in an important section of the San Francisco River (Northeast Brazil): distribution profile, accumulation mechanisms, and risks of dissemination through the food chain. Journal of Pollution Effects \& Control, 5(2), ID: 1000193, 2017.

Petricca, C., Moloo, Z., \& Stoisser, M. (2020). Hazardous e-waste recycling in Agbogbloshie, Accra, Ghana. Environmental Justice Atlas. Retrieved on Mar 23, 2021, from https://ejatlas.org/conflict/agbogbloshie-e-waste-landfill-ghana

Phoonaploy, U., Tengjaroenkul, B., \& Neeratanaphan, L. (2019). Effects of electronic waste on cytogenetic and physiological changes in snakehead fish (Channa striata). Environmental Monitoring and Assessment, 191, 363. https://doi.org/10.1007/s10661-019-7509-x

Popoola, O.E., Popoola, A.O., \& Purchase, D. (2019). Levels of awareness and concentrations of heavy metals in the blood of electronic waste scavengers in Nigeria. Journal of Health \& Pollution, 9(21), 1-10. https://doi.org/10.5696/2156-9614-9.21.190311

Quan, S-X., Yan, B., Yang, F., Li, N., Xiao, X-M., \& Fu, J-M. (2015). Spatial distribution of heavy metal contamination in soils near a primitive e-waste recycling site. Environmental Science and Pollution Research, 22, 1290-1298. https://doi.org/10.1007/s11356-014-3420-8

Sankhla, M. S., Kumari, M., Sharma, K., Kushwah, R. S., \& Kumar, R. (2018). Heavy metal pollution of Holy River Ganga: a review. International Journal of Research, 5(1), 424-436.

Sanusi, A. I. (2016). Heavy metal profile of Oreochromis niloticus harvested from e-waste polluted vials and associated Fungi. Advances in Microbiology, 6, 555-565. https://doi.org/10.4236/aim.2016.68056

Schecter, A., Szabo, D. T., Miller, J., Gent, T. L., Malik-Bass, N., Petersen, M., ... \& Birnbaum, L. S. (2012). Hexabromocyclododecane (HBCD) Stereoisomers in U.S. Food from Dallas, Texas. Environmental Health Perspectives, 120(9), 1260-1264. https://doi.org/10.1289/ehp.1204993

Shi, J., Zheng, G.J.S., Wong, M.H., Liang, H., Li, Y., Wu, Y., Li, P., \& Liu, W. (2016). Health risks of polycyclic aromatic hydrocarbons via fish consumption in Haimen bay (China), downstream of an e-waste recycling site (Guiyu). Environmental Research, 147, 233-240. https://doi.org/10.1016/j.envres.2016.01.036

Siddiqi, M. A., Laessig, R. H., \& Reed, K. D. (2003). Polybrominated diphenyl ethers (PBDEs): new pollutantsold diseases. Clinical Medicine \& Research, 1(4), 281-290. https://doi.org/10.3121/cmr.1.4.281

Singh, N., Duan, H., Yin F., Song Q., \& Li, J. (2018). Characterizing the materials composition and recovery potential from waste mobile phones: a comparative evaluation of cellular and smart phones. ACS Sustainable Chemistry \& Engineering, 6(4), 13016-13024. https://doi.org/10.1021/acssuschemeng.8b02516

Singh, M., Thind, P. S., \& John, S. (2018). Health risk assessment of the workers exposed to the heavy metals in e-waste recycling sites of Chandigarh and Ludhiana, Punjab, India. Chemosphere, 203, 426-433. https://doi.org/10.1016/j.chemosphere.2018.03.138

Skerfving, S., \& Bergdahl, I. A. (2007). Lead. Handbook on the Toxicology of Metals (Third Edition), 2007.

Sthiannopkao, S., \& Wong, M. H. (2013). Handling e-waste in developed and developing countries: Initiatives, practices, and consequences. Science of the Total Environment, 463-464, 1147-1153. https://doi.org/10.1016/j.scitotenv.2012.06.088

Suja, F., Rahman, R. A., Yusof, A., \& Masdar, M. S. (2014). E-waste management scenarios in Malaysia. Journal of Waste Management, 2014, ID 609169. https://doi.org/10.1155/2014/609169

Sun, Yu-xin., Luo, Xiao-jun., Mo, L., He, Ming-jing., Zhang, Q, Chen, She-jun., Zou, Fa-sheng., \& Mai, Bi-xian. 
(2012). Hexabromocyclododecane in terrestrial passerine birds from e-waste, urban and rural locations in the Pearl River Delta, South China: Levels, biomagnification, diastereoisomer- and enantiomer-specific accumulation. Environmental Pollution, 171, 191-198. https://doi.org/10.1016/j.envpol.2012.07.026

Tiseo, I. (2021). Global e-waste generation by major country. Statista. Accessed on May 3, 2021.

Tue, N. M., Sudaryanto, A., Minh, T.B., Isobe, T., Takahashi, S., Viet, P.H., \& Tanabe, S. (2010). Accumulation of polychlorinated biphenyls and brominated flame retardants in breast milk from women living in Vietnamese e-waste recycling sites. Science of the Total Environment, 408, 2155-2162. https://doi.org/10.1016/j.scitotenv.2010.01.012

Viberg, H., Johansson, N., Fredriksson, A., Eriksson, J., Marsh, G., \& Eriksson, P. (2006). Neonatal Exposure to Higher Brominated Diphenyl Ethers, Hepta-, Octa-, or Nonabromodiphenyl Ether, Impairs Spontaneous Behavior and Learning and Memory Functions of Adult Mice. Toxicological Science, 92(1), 211-218. https://doi.org/10.1093/toxsci/kfj196

Waalkes, M. P. (2000). Cadmium carcinogenesis in review. Journal of Inorganic Biochemistry, 79, 241-244. https://doi.org/10.1016/S0162-0134(00)00009-X

Wang, Y., Tian, Z., Zhu, H., Cheng, Z., Kang, M., Luo, C., Li, J., \& Zhang, G. (2012). Polycyclic aromatic hydrocarbons (PAHs) in soils and vegetation near an e-waste recycling site in South China: Concentration, distribution, source, and risk assessment. Science of The Total Environment, 439, 187-193, https://doi.org/10.1016/j.scitotenv.2012.08.018

Wong, C. S. C., Dusgoren-Aydin, N. S., Aydin, A., \& Wong, M. H. (2007). Evidence of excessive releases of metals from primitive e-waste processing in Guiyu, China. Environmental Pollution, 148, 62-72. https://doi.org/10.1016/j.envpol.2006.11.006

Wu, J. P., Luo, X. J., Zhang, Y., Luo, Y., Chen, S. J., Mai, B. X., \& Yang, Z. Y. (2008). Bioaccumulation of polybrominated diphenyl ethers (PBDEs) and polychlorinated biphenyls (PCBs) in wild aquatic species from an electronic waste (e-waste) recycling site in South China. Environment International, 34, 1109-1113, 2008. https://doi.org/10.1016/j.envint.2008.04.001

Wu, Q., Leung, J. Y. S., Geng, X., Chen, S., Huang, X., Li, H., ... \& Lu, Y. (2015). Heavy metal contamination of soil and water in the vicinity of an abandoned e-waste recycling site: Implications for dissemination of heavy metals. Science of the Total Environment, 506-507, 271-225. https://doi.org/10.1016/j.scitotenv.2014.10.121

Wu, P. F., Yu, L. L., Li, L., Zhang, Y., \& Li, X. H. (2016). Maternal transfer of dechloranes and their distribution among tissues in contaminated ducks. Chemosphere, 150, 514-519. https://doi.org/10.1016/j.chemosphere.2015.11.008

Wu, Q., Leung, J. Y. S., Du, Y., Kong, D., Shi, Y., Wang, Y., \& Xiao, T. (2019). Trace metals in e-waste lead to serious health risk through consumption of rice growing near an abandoned e-waste recycling site: Comparisons with PBDEs and AHFRs. Environmental Pollution, 247, 46-54. https://doi.org/10.1016/j.envpol.2018.12.051

Yan, Y., Song, L. X., Long, L. D., \& Jiang, Y. Y. (2013). Effects of environmental lead pollution on blood lead and sex hormone levels among occupationally exposed group in an e-waste dismantling area. Biomedical and Environmental Sciences, 26(6), 474-484. 10.3967/0895-3988.2013.06.008

Yang, S., Gu, S., He, M., Tang, X., Q.Ma, L., Xu, J., \& Liu, X. (2020). Policy adjustment impacts Cd, Cu, Ni, Pb and $\mathrm{Zn}$ contamination in soils around e-waste area: Concentrations, sources, and health risks. Science of the Total Environment, 741, 140442-140450. https://doi.org/10.1016/j.scitotenv.2020.140442

Youshida A., Terazono, A., Ballesteros, F.C., Nguyen, D-Q., Sukandar, S., Kojima, M., \& Sakata, S. (2016). E-waste recycling processes in Indonesia, the Philippines, and Vietnam: A case study of cathode ray tube TVs and monitors. Resources, Conservation and Recycling, 106, 48-58. https://doi.org/10.1016/j.resconrec.2015.10.020

Zeng, Y. H., Luo, X. J., Zheng, X. B., Tang, B., Wu., J. P., \& Mai, B. X. (2014). Species-specific bioaccumulation of halogenated organic pollutants and their metabolites in fish serum from an e-waste site, South China. Archives of Environmental Contamination and Toxicology, 67, 348-357. https://doi.org/10.1007/s00244-014-0040-8

Zeng, X., Xu, X., Boezen, H. M., \& Huo, X. (2016). Children with health impairments by heavy metals in an e-waste recycling área. Chemosphere, 148, 408-415. https://doi.org/10.1016/j.chemosphere.2015.10.078 
Zhang, H., Song, Y., Wang, F., Li, Y., Wang, H., \& Yang, L. (2018). Identification of Cu-binding proteins in embryos of germinating rice in response to $\mathrm{Cu}$ toxicity. Acta Physiologiae Plantarum, 40, 158, 2018. https://doi.org/10.1007/s11738-018-2729-1

Zhang, T., Ruan, J., Zhang, B., Lu, S., Gao, C., Huang, L., Bai, X., Xie, L., Gui, M., \& Qiu, Rong-liang. (2019). Heavy metals in human urine, foods and drinking water from an e-waste dismantling area: Identification of exposure sources and metal-induced health risk. Ecotoxicology and Environmental Safety, 169, 707-713. https://doi.org/10.1016/j.ecoenv.2018.10.039

Zhang, W., Xie, H.Q., Zou, X., Li, J., Xu, L., Li, Y., Zhou, Z., Jin, T., Ma, D., \& Zhao, B. (2019). The toxic effects of in situ exposure of a native fish species (Anabas testudineus) to electronic waste pollution. Science of the Total Environment, 690, 1170-1177. https://doi.org/10.1016/j.scitotenv.2019.06.479

\section{Copyrights}

Copyright for this article is retained by the author(s), with first publication rights granted to the journal.

This is an open-access article distributed under the terms and conditions of the Creative Commons Attribution license (http://creativecommons.org/licenses/by/4.0/). 